\title{
Analytical Methods for Determination of Muscle Relaxant Thiocolchicoside in Pharmaceutical Preparations- A Review
}

\author{
J.K. Rajput, P.H. Patil, S. J. Surana and A. A. Shirkhedkar ${ }^{*}$ \\ Department of Pharmaceutical Chemistry, R. C. Patel Institute of Pharmaceutical Education and Research, Shirpur, \\ Dist. Dhule (MS), 425405 India
}

\begin{abstract}
Thiocolchicoside is a centrally acting muscle relaxant and used in combination with many NSAIDs for the treatment of various musculoskeletal disorders. As it is less sedative than other centrally acting muscle relaxants hence frequently prescribed for low back pain (LBP), orthopedic, traumatic and rheumatologic disorders. It is available in market in single component and as multicomponent formulations. Various analytical methods are available for determination of thiocolchicoside in drug substances and formulated products. The present article summarizes more than 100 analytical methods including all types of chromatographic, UV-Visible spectrophotometry and radio immune assays with their percentage of utility for determination of thiocolchicoside in biological matrices, bulk material and different pharmaceutical formulations.
\end{abstract}

Keywords: Analytical methods, thiocolchicoside.

\section{INTRODUCTION}

Thiocolchicoside (THC) is a semisynthetic derivative of cholchicoside (natural compound) which is obtained from the seeds of Gloriosa superb and Colchicum autumnale. It is an analogue of colchicines, as they share the same benzo (alpha) heptalenic moiety [1]. It is used as muscle relaxant for the treatment of painful muscle contractions in acute and chronic rheumatic conditions, in traumatology and in patients with acute low back pain [2]. Moreover, Antiinflammatory and analgesic effects of this drug have also been reported in animal models [3]. It is used since several years in the European countries, but in India the first formulation containing thiocolchicoside was approved in the year 2008 [4]. THC is available in combination therapy with many NSAIDs for treatment of acute low back pain and painful muscle spasms.

\section{CHEMISTRY}

Thiocolchicoside (THC) (Fig. 1) is a 2-Glucoside analog of Thiocolchicine and known as 2-demethoxy-2- glucosidoxythiocolchicine. The Molecular formula is $\mathrm{C}_{27} \mathrm{H}_{33} \mathrm{NO}_{10} \mathrm{~S}$; and molecular weight is $563.62 \mathrm{~g}$ it occurs as yellow crystalline powder and is soluble in water, methanol, $0.1 \mathrm{~N} \mathrm{HCl}, 0.1 \mathrm{~N}$ $\mathrm{NaOH}$. It contains not less than 98.0 per cent and not more than 102.0 per cent of $\mathrm{C} 27 \mathrm{H} 33 \mathrm{NO}_{10} \mathrm{~S}$. Thiocolchicine is chemically, $N$-[(7S)-5,6,7,9-Tetrahydro-1,2,3-trimethoxy-10(methylthio)-9-oxabenzo[a]heptalen-7-yl]acetamide and its semi-synthetic derivative THC is, $N$-[(7S)-2-(3,4,5trihydroxy-6-hydroxymethyl-tetrahydropyran-2-yloxy)-5,6, 7,9-Tetrahydro-1,3-dimethoxy-10-(methylthio)-9-oxabenzo [a]heptalen-7-yl]acetamide [5].

*Address correspondence to this author at the Department of Pharmaceutical Chemistry, R. C. Patel Institute of Pharmaceutical Education and Research, Shirpur, Dist. Dhule (MS), 425 405, India; Tel: +91-9823691502; Fax:+91-2563251808; E-mail: shirkhedkar@gmail.com

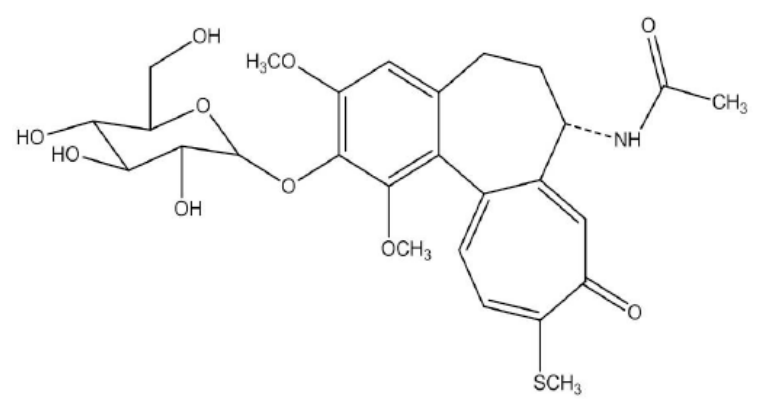

Fig. (1). Chemical structure of thiocolchicoside.

\section{PHARMACOLOGY}

\section{Mechanism of Action}

THC is a centrally acting Non-benzodiazepine muscle relaxant. It acts as a weak postsynaptic GABA agonist [6]. TCC has been used clinically for more than 35 years as a musclerelaxant, anti-inflammatory, and analgesic drug, but its molecular targets and mechanisms of action are still under investigation. This compound has been shown to inhibit the binding of $\left[{ }^{3} \mathrm{H}\right]$ GABA (g-aminobutyric acid) or $\left[{ }^{3} \mathrm{H}\right]$ strychnine to rat cerebro-cortical or spinal cord membranes, respectively, in vitro as well as to corresponding autoradiographic sections in vivo. Moreover, TCC was shown to interact preferentially with a subpopulation of GABA-ARs with low-affinity binding sites for GABA. Although its precise mechanisms of action remain unknown, TCC has been thought to act as a GABA-AR agonist that induces depression of the central nervous system and, in turn, myorelaxation [7].

\section{Pharmacokinetics}

On IM administration THC shows Cmax values of 113 $\mathrm{ng} / \mathrm{mL}$ (4 mg dose) and $175 \mathrm{ng} / \mathrm{mL}$ (8 mg dose) in $30 \mathrm{~min}$. After oral administration, no THC is detected in plasma. Only two metabolites were observed with maximum plasma concentrations one hour after THC administration [8]. 


\section{Dosage Forms and Recommended Dose}

Oral, parenteral and topical formulations of $\mathrm{THC}$ are available in India. The maximum recommended oral dose is $8 \mathrm{mg}$ every 12 hours for not more than 7 consecutive days. The maximum intramuscular dose should be $4 \mathrm{mg}$ every 12 hours, for up to 5 days [8].

\section{Contraindications}

THC is contraindicated in patients hypersensitive to the active substance, during the entire pregnancy period, during lactation and in women of childbearing potential not using contraception. The drug is also contraindicated in children less than 16 years of age $[8,9]$.

\section{Adverse Effects}

THC has shown some side effects like anaphylactic reactions, such as pruritus, urticaria, angioneurotic oedema; anaphylactic shock following intramuscular injection, somnolence, vasovagal syncope, usually occurring in minutes following the intramuscular injection; diarrhea, gastralgia, nausea, vomiting and allergic skin reaction and phototoxicity.

On $21^{\text {st }}$ November 2013, the European Medicines Agency's Committee on Human Medicinal Product recommended that the authorized uses for THC containing medicines for use by mouth or injection should be restricted across the European Union. In addition, the dose of thiocolchicoside by mouth or injection should be restricted [8].

Thiocolchicoside given at doses of $6-12 \mathrm{mg} / \mathrm{kg}$ is unable to induce, in intact rats, any electrical or behavioural paroxysmal activity. However, when this compound is applied topically to the pia, given by microinjection to cerebral cortex, or administered parenterally at doses of $6 \mathrm{mg} / \mathrm{kg}$ to rats with minimal lesions of the dura and arachnoid membranes, it displays within a few minutes, a powerful convulsant activity. It is also reported that thiocolchicoside presented seizures in a patient when treated with a much lower dose $(0.25$ $\mathrm{mg} / \mathrm{kg}$ for the cumulative dose or $0.05 \mathrm{mg} / \mathrm{kg}$ for a single dose) $[10,11]$.

\section{Recent Safety Alerts for Thiocolchicoside}

The review of thiocolchicoside was triggered by the Italian medicines regulatory agency, AIFA, following new experimental evidence which suggested that THC was broken down in the body into a metabolite called $\mathrm{M}_{2}$ or SL59.0955 that could damage dividing cells, resulting in aneuploidy (an abnormal number or arrangement of chromosomes) [9].

\section{ANALYTICAL METHODS FOR DETERMINATION OF THIOCOLCHICOSIDE}

The analysis of pharmaceuticals is an integral part of drug development process. From many years; analytical techniques like UV/Vis-Spectrophotometry, Spectrofluorimetry, Atomic Absorption Spectrometry, Capillary-Electrophoresis, Liquidchromatography, Gas-chromatography Mass-spectrometry, Luminescence, Voltammetry and Polarography have been studied for the analysis of pharmaceutical compounds. Amongst all these methods, chromatographic methods have been widely exploited and preferred over other methods [12]. THC is a commonly used muscle relaxant in the treatment of acute painful muscle spasms. It is available in combined treatment with many non-steroidal anti-inflammatory drugs (NSAIDs) like Aceclofenac, Diclofenac, Paracetamol, Ketoprofen, Etodolac, Etoricoxib, Lornoxicam and Floctafenine and the literature reports vast number of analytical methods such as UV-spectrophotometry, HPLC, TLC-densitometry and LC-MS/MS for the determination of THC in biological matrices, bulk material and the corresponding pharmaceutical formulations.

Consequently, the objective of the present review is to compile the analytical methods published so far for estimation of THC in biological samples including metabolites and degradants, bulk materials and pharmaceutical formulations. The percentage utility of these techniques is calculated and shown in Fig. (2), from which it can be noticed that HighPerformance Liquid Chromatography (HPLC) and Spectrophotometric methods have been most extensively used. Apart from this, the present review will be useful for selecting the diluents Fig. (3) and the analytical procedure for the assay of THC with different concentrations ranges, selective accuracy and precision in various biological material or pharmaceuticals.

\section{Spectrophotometry [13-29] and Spectrofluorimetry [30]}

In the literature, nearly twenty seven UV- Spectrophotometric methods have been reported so far for estimation of THC alone and in combined dosage forms as well as a single Spectrofluorimetry method has been also established for THC from injection. Table $\mathbf{1}$ illustrates the summary of the reported UV-Spectrophotometric and Spectrofluorimetry methods indicating the basic principle, matric used, $\lambda \max$, solvent and linearity range.

\section{Methods for Analysis as a Single Component}

Eight methods for estimation of THC in a capsule dosage form as a single component have been developed. The first, second and third method employ first order, second order and third order derivative spectroscopy to reduce spectral interference. The fourth method employs selection of area under curve in wavelength region of $254-264 \mathrm{~nm}$ using 0.1 $\mathrm{N}$ Sodium hydroxide solution prepared in double distilled water [13]. Two simple and sensitive spectrophotometric methods have been developed for the quantitative estimation of THC from its capsule formulation. The first method is a zero order UV spectrophotometric method using distilled water as solvent; the drug showed absorption maximum at $259.8 \mathrm{~nm}$ and linearity was observed in the concentration range of $5.0-50 \mu \mathrm{g} / \mathrm{mL}$. The second method is area under curve selecting the wavelength range of $269.8-249.8 \mathrm{~nm}$ [14]. In other method, utilizing UV-Spectrophotometric procedure, based on the linear relationship between the THC concentration and the $\lambda \max$ amplitude at $279 \mathrm{~nm}$ [15].

\section{Methods for Analysis in Combined Dosage form with Other Drugs}

As THC is available with many NSAIDS, analgesics and antipyretics in combined pharmaceutical formulations; literature revealed range of UV-Spectrophotometric methods for simultaneous determination of $\mathrm{THC}$ in combined dosage forms. 


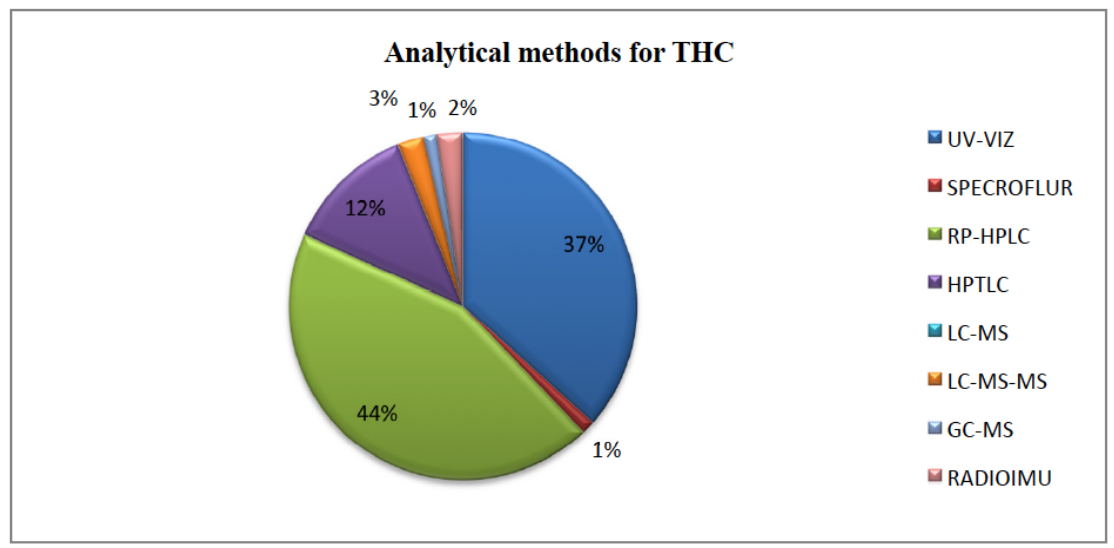

Fig. (2). Different analytical methods employed for determination of thiocolchicoside.

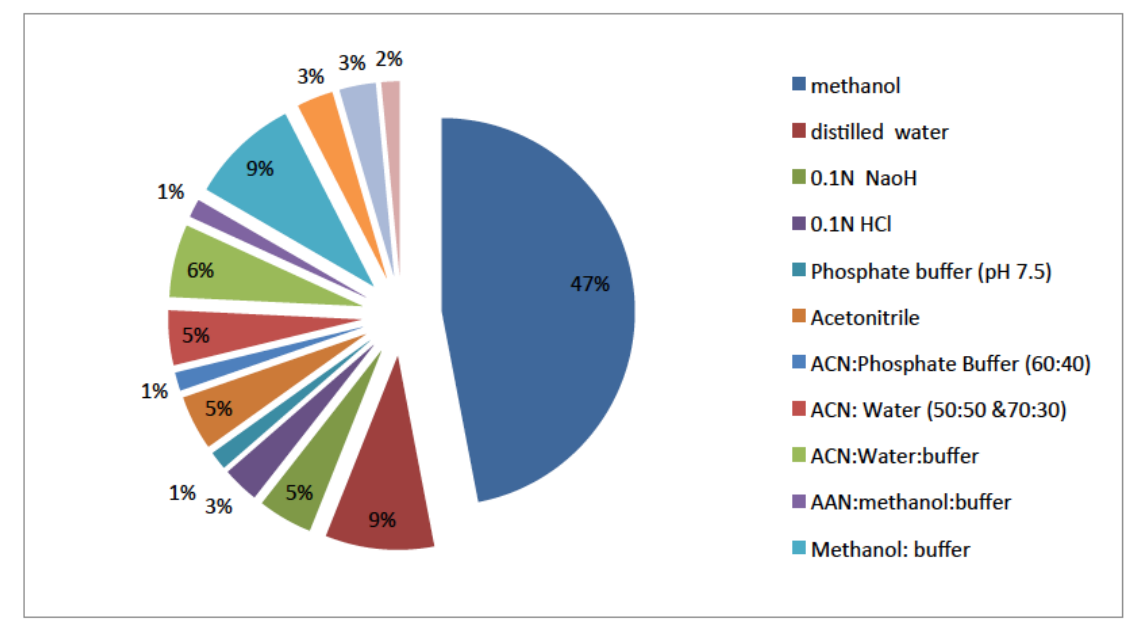

Fig. (3). Diluents used for the analysis of THC in different analytical methods.

Two simple, rapid, accurate and economical methods have been developed for the estimation of THC and DCF-P in capsules. The first method; involves formation of Q-absorbance equation at 264 (isoabsorptive point) and at $259 \mathrm{~nm}$, while the second method; involves formation of simultaneous equation at 259 and $271 \mathrm{~nm}$, using water as solvent [16].

Two methods; absorption correction and area under curve have been established for the quantitative estimation of THC and DCF-P from tablet formulation using methanol as a solvent. In absorption correction method, quantitative estimation of THC was carried out by subtracting interference of diclofenac using experimentally calculated absorption factor, also Beer's plot was constructed for DCFP and THC in solution mixture at different concentration $(25: 4,37.5: 6,50: 8$, $62.5: 10,75: 12 \mu \mathrm{g} / \mathrm{mL}$ ) levels. For the simultaneous equations using area under curve; $252.56-260.59 \mathrm{~nm}\left(\lambda_{1}-\lambda_{2}\right)$ and $278.51-285.53 \mathrm{~nm}\left(\lambda_{3}-\lambda_{4}\right)$ have been selected as a sampling wavelength ranges for estimation of DCFP and THC [17].

Two methods for simultaneous determination of DCFP with THC in combined dosage form have been developed. The first method is based on first derivative of the ratio spec$\operatorname{tra}\left({ }^{1} \mathrm{DD}\right)$ measuring the amplitudes at $268.78 \mathrm{~nm}$ and 355.62 $\mathrm{nm}$. For the second method, two wavelengths were selected for each drug in a way so that the difference in absorbance is zero for another drug [18]. A simple method employed the formation and solving of simultaneous equation using 259 $\mathrm{nm}$ and $277 \mathrm{~nm}$ as the wavelength for forming equation has been also developed for DCFP with THC using $0.1 \mathrm{~N} \mathrm{NaOH}$ as a solvent [19]. A single method, using multicomponent mode of analysis of the instrument is used for the simultaneous estimation of the two drugs THC and DCF-P respectively [20]. Three spectrophotometric methods $(\mathrm{A}-\mathrm{C})$ were described for simultaneous determination of THC with DCF$\mathrm{S}$ in capsule formulation. The first 'method A' is absorbance correction method and determines concentration of DCFS directly from calibration plot by measuring absorbance at $276.6 \mathrm{~nm}$ and THC was determined after correction for absorbance of DCF-S at $372.8 \mathrm{~nm}$. The second method is based on first order derivative spectroscopy to overcome spectral interference from other drug and wavelengths $278.6 \mathrm{~nm}$ and $243.2 \mathrm{~nm}$ were selected for the determination of the DCFS and THC, respectively. In the third method, diclofenac sodium was determined by plotting the difference in absorbance at 244 and $269 \mathrm{~nm}$ (difference is zero for THC) against the concentration of DCFS. Similarly for the determination of THC, the difference in absorbance at $266.8 \mathrm{~nm}$ and $290 \mathrm{~nm}$ (difference is zero for DCFS) was plotted against the concentration of DCFS [21].

Two methods for simultaneous estimation of THC and DCFP in combined dosage form have been described. In the first method; the wavelengths $276.5 \mathrm{~nm}$ ( $\lambda$ max of DCFP) and 
Table 1. Spectrophotometric methods used for determination of thiocolchicoside alone and in combined dosage form.

\begin{tabular}{|c|c|c|c|c|c|c|c|c|}
\hline $\begin{array}{l}\text { Sr. } \\
\text { No. }\end{array}$ & $\begin{array}{l}\text { Name of } \\
\text { drug }\end{array}$ & $\begin{array}{l}\text { Sample } \\
\text { matrix }\end{array}$ & & Method & $\begin{array}{l}\text { Detection } \\
(\lambda \max ) \mathrm{nm}\end{array}$ & Linearity range & Comments & Ref. \\
\hline \multirow{4}{*}{1} & \multirow{4}{*}{$\mathrm{THC}$} & \multirow{4}{*}{ Capsule } & A & Zero order & $259.0 \mathrm{~nm}$ & \multirow{4}{*}{$\mathrm{THC}-2.5-50 \mu \mathrm{g} / \mathrm{mL}$} & \multirow{4}{*}{$\begin{array}{l}\text { Simple and } \\
\text { accurate }\end{array}$} & \multirow{4}{*}[13]{} \\
\hline & & & B & First order & $252.0 \mathrm{~nm}$ & & & \\
\hline & & & $\mathrm{C}$ & Second order & $260.0 \mathrm{~nm}$ & & & \\
\hline & & & $\mathrm{D}$ & AUC & $254.0-264.0 \mathrm{~nm}$ & & & \\
\hline \multirow{2}{*}{2} & \multirow{2}{*}{$\mathrm{THC}$} & \multirow{2}{*}{ Capsule } & A & Zero order & $259.8 \mathrm{~nm}$ & & \multirow{2}{*}{$\begin{array}{l}\text { Simple and } \\
\text { economical }\end{array}$} & \multirow{2}{*}[14]{} \\
\hline & & & B & AUC & $269.8-259.8 \mathrm{~nm}$ & & & \\
\hline 3 & $\mathrm{THC}$ & Capsule & & Zero order & $257.0 \mathrm{~nm}$ & THC-2-38 mg/mL & Simple & {$[15]$} \\
\hline \multirow{2}{*}{4} & \multirow{2}{*}{$\mathrm{THC}+\mathrm{DCF}$} & \multirow{2}{*}{ Capsule } & A & Q-value/Analysis & \multirow{2}{*}{$264 \mathrm{~nm}$ and $259 \mathrm{~nm}$} & \multirow{2}{*}{$\begin{array}{l}\text { THC- } 2-40 \mu \mathrm{g} / \mathrm{mL} \\
\text { DCF- } 1-50 \mu \mathrm{g} / \mathrm{mL}\end{array}$} & \multirow{2}{*}{ Economic } & \multirow{2}{*}[16]{} \\
\hline & & & B & Simultaneous equation & & & & \\
\hline \multirow[b]{2}{*}{5} & \multirow[b]{2}{*}{$\mathrm{THC}+\mathrm{DCF}$} & \multirow[b]{2}{*}{ Tablets } & A & Absorption correction & $264.99 \mathrm{~nm}$ and $373.84 \mathrm{~nm}$ & \multirow{2}{*}{$\begin{array}{l}\text { DCF-25-75 } \mu \mathrm{g} / \mathrm{mL} \\
\text { THC-4-12 } \mu \mathrm{g} / \mathrm{mL}\end{array}$} & \multirow{2}{*}{$\begin{array}{l}\text { Higher linearity } \\
\text { range }\end{array}$} & \multirow[b]{2}{*}[17]{} \\
\hline & & & B & $\begin{array}{l}\text { Area Under Curve } \\
\text { (AUC) }\end{array}$ & $\begin{array}{l}\text { DCF } 252.56-260.59 \mathrm{~nm} \text { and } \\
\text { THC 278.51-285.53 nm }\end{array}$ & & & \\
\hline \multirow{2}{*}{6} & \multirow{2}{*}{$\mathrm{THC}+\mathrm{DCF}$} & \multirow{2}{*}{ Tablets } & A & Ratio Derivative & $268.78 \& 355.62 \mathrm{~nm}$ & $12.5-75 \mu \mathrm{g} / \mathrm{m} 1$ & \multirow{2}{*}{$\begin{array}{l}\text { Different linear- } \\
\text { ity and complex }\end{array}$} & \multirow{2}{*}[18]{} \\
\hline & & & B & Dual Wavelength & $252.47 \mathrm{~nm}$ and $260.74 \mathrm{~nm}$ & $25-75 \mu \mathrm{g} / \mathrm{mL}$ & & \\
\hline 7 & $\mathrm{THC}+\mathrm{DCF}$ & Capsule & & nultaneous equation & $259 \mathrm{~nm}$ and $277 \mathrm{~nm}$ & $\begin{array}{c}\text { THC } 4-24 \mu \mathrm{g} / \mathrm{mL} \\
\& \text { DCF } 10-60 \mu \mathrm{g} / \mathrm{mL}\end{array}$ & $\begin{array}{l}\text { Simple and } \\
\text { economical }\end{array}$ & {$[19]$} \\
\hline 8 & $\mathrm{THC}+\mathrm{DCF}$ & Capsule & & llticomponent mode & $254,259,265,271,286$ & $\begin{array}{l}\text { THC-20-100 } \mu \mathrm{g} / \mathrm{mL} \text { and } \\
\text { DCF-20-100 } \mu \mathrm{g} / \mathrm{mL}\end{array}$ & Economical & {$[20]$} \\
\hline & & & A & $\begin{array}{c}\text { Absorbance correction } \\
\text { method }\end{array}$ & $276.6 \mathrm{~nm}$ and $372.8 \mathrm{~nm}$ & DCF-5-30 u $/ \mathrm{ml}$ & & \\
\hline 9 & $\mathrm{THC}+\mathrm{DCF}$ & Capsule & B & First order derivative & $278.6 \mathrm{~nm}$ and $243.2 \mathrm{~nm}$ & and $\mathrm{THC}-10-60 \mu \mathrm{g} / \mathrm{mL}$ & Sensitive & [21] \\
\hline & & & $\mathrm{C}$ & Dual wavelength & $244 \mathrm{~nm}$ and $269 \mathrm{~nm}$ & & & \\
\hline 10 & & Copol & A & $\begin{array}{c}\text { Simultaneous Equation } \\
\text { method }\end{array}$ & $\begin{array}{c}260.0 \mathrm{~nm} \mathrm{THC} \text { and } 276.5 \mathrm{~nm} \\
\text { DCF }\end{array}$ & THC-1-10 $\mu \mathrm{g} / \mathrm{mL}$ and DCF- & Easy and eco- & \\
\hline 10 & $1 \mathrm{HC}+\mathrm{DCF}$ & Capsule & B & $\begin{array}{c}\text { Absorbance Correction } \\
\text { method }\end{array}$ & $\begin{array}{l}276.5 \mathrm{~nm} \text { DCF, } 373.0 \mathrm{~nm} \text { is } \\
\text { isoabsorptive point of THC }\end{array}$ & $6.25-62.5 \mu \mathrm{g} / \mathrm{mL}$ & nomical & {$[22]$} \\
\hline 11 & $\mathrm{THC}+\mathrm{DCF}$ & Capsule & A & $\begin{array}{l}\text { absorption correction } \\
\text { method }\end{array}$ & $\begin{array}{c}\text { THC-397.80 nm and DCF- } \\
271.0 \mathrm{~nm}\end{array}$ & $\begin{array}{l}\text { THC-5-35 } \mu \mathrm{g} / \mathrm{mL} \\
\text { and } 10-70 \mu \mathrm{g} / \mathrm{mL}\end{array}$ & Accurate & {$[23]$} \\
\hline 12 & $\begin{array}{l}\mathrm{THC}+ \\
\mathrm{ACE}\end{array}$ & Tablet & A & AUC & $\begin{array}{l}264.5-254.5 \mathrm{~nm} \text { for } \mathrm{THC} \text { and } \\
279.0-269.0 \mathrm{~nm} \text { for ACE }\end{array}$ & THC and DCF- $4-36 \mu \mathrm{g} / \mathrm{mL}$ & $\begin{array}{l}\text { Precise and } \\
\text { selective }\end{array}$ & {$[24]$} \\
\hline 13 & $\begin{array}{l}\text { THC+ } \\
\text { ETD }\end{array}$ & Tablet & Abs & rbance Ratio Method & $260 \mathrm{~nm}$ and $232 \mathrm{~nm}$ & 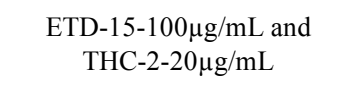 & Selective & {$[25]$} \\
\hline 14 & $\mathrm{THC}+$ & Tablet & & sorbance correction & $370 \mathrm{~nm}$ and $255 \mathrm{~nm}$ & THC $4-40 \mu \mathrm{g} / \mathrm{mL}$ and DKET 5- & Accurate and & {$[26]$} \\
\hline 14 & DXKET & Iablet & & rst order derivative & $232 \mathrm{~nm}$ and $242 \mathrm{~nm}$ & $50 \mu \mathrm{g} / \mathrm{mL}$ & sensitive & {$[26]$} \\
\hline 15 & $\mathrm{THC}+\mathrm{KFT}$ & Tablet & & rst order derivative & $\begin{array}{l}\text { THC } 233.0 \mathrm{~nm} \text { and } \\
\text { KET } 243.0 \mathrm{~nm}\end{array}$ & $\begin{array}{l}\text { THC- } 3-15 \mu \mathrm{g} / \mathrm{mL} \text { and } \\
\text { KET-12-60 } \mu \mathrm{g} / \mathrm{mL}\end{array}$ & Simple and & \\
\hline 15 & $1 \mathrm{HC}+\mathrm{KE} 1$ & Iablet & & sorbance correction & $\begin{array}{l}\text { THC } 372.0 \mathrm{~nm} \text {, } \\
\text { KET } 260.0 \mathrm{~nm} .\end{array}$ & $\begin{array}{c}\text { THC- } 1-5 \mu \mathrm{g} / \mathrm{mL} \text { and KET- } \\
10-50 \mu \mathrm{g} / \mathrm{mL}\end{array}$ & selective & {$[2 /]$} \\
\hline 16 & $\begin{array}{l}\mathrm{PCM}+ \\
\mathrm{THC}+ \\
\mathrm{ACE}\end{array}$ & Tablet & & lticomponent mode & $\begin{array}{l}\text { PCM-256 nm, } \\
\text { THC } 258 \mathrm{~nm}, \\
\text { ACE } 270 \mathrm{~nm} .\end{array}$ & $\begin{array}{c}\text { PCM- } 1-25 \mu \mathrm{g} / \mathrm{mL} \text {, THC- } \\
2.5-25 \mu \mathrm{g} / \mathrm{mL} \text { and ACE- } \\
1-25 \mu \mathrm{g} / \mathrm{mL}\end{array}$ & Economical & {$[28]$} \\
\hline 17 & $\begin{array}{c}\mathrm{PCM}+ \\
\mathrm{THC}+ \\
\mathrm{ACE}\end{array}$ & Tablet & & lticomponent mode & $\begin{array}{l}\text { PCM } 249 \mathrm{~nm}, \\
\text { THC } 258 \mathrm{~nm}, \\
\text { ACE } 276 \mathrm{~nm} .\end{array}$ & $\begin{array}{c}\text { PCM }-5-25 \mu \mathrm{g} / \mathrm{mL} \\
\text { THC-1-5 } \mu \mathrm{g} / \mathrm{mL} \text { and ACE- } \\
1-5 \mu \mathrm{g} / \mathrm{mL}\end{array}$ & Economical & [29] \\
\hline 18 & $\mathrm{THC}$ & Injection & & pectrofluorimetry & $289 \mathrm{~nm}$ and $366 \mathrm{~nm}$. & $\mathrm{THC}-1-10 \mu \mathrm{g} / \mathrm{mL}$ & Specific & {$[30]$} \\
\hline
\end{tabular}


$373.0 \mathrm{~nm}$ (where DCFP does not interfere in absorbance of THC) were selected for analysis by proposed method, while the second method; involves formation of simultaneous equation at 260 and $275.5 \mathrm{~nm}$, using $0.1 \mathrm{~N} \mathrm{NaOH}$ as solvent [22].

A simple UV-Spectrophotometric absorption correction method has been reported, which is based upon determination of THC at $397.80 \mathrm{~nm}$ and DCF-P at $271.0 \mathrm{~nm}$, in distilled water [23].

Only one AUC method is available for simultaneous analysis of THC with ACE. The method employed selection of area under curve in wavelength region of $264.5-254.5$ $\mathrm{nm}$ for THC; 279.0 - $269.0 \mathrm{~nm}$ for Aceclofenac and solving the equations [24].

An absorbance ratio (Q-analysis) UV spectrophotometric method has been developed for the simultaneous determination of THC and ETD from the combined tablet dosage form using $232 \mathrm{~nm}$ as isoabsorptive point and $0.1 \mathrm{~N} \mathrm{HCl}$ as solvent [25]. Two methods, i.e. Absorbance correction and First order derivative spectroscopy are also reported for simultaneous estimation of THC with DXKET using methanol as solvent. The amount of drug determined by proposed methods ranges from 99.8 to $100.2 \%$ for both. The method reports recovery study values of THC and DXKET $99.8 \%$ and $100.2 \%$, respectively for both the methods with RSD less than $2 \%$. [26] Few other methods, First order derivative spectroscopic (\% label claimed $99.94 \%$ for THC and 99.60 $\%$ for KET) and Absorbance correction method (\% label claimed $100.32 \%$ for THC and $99.95 \%$ for KET) is presented in literature for estimation of THC with KET using distilled water as solvent [27]. Two methods using multicomponent mode of analysis are also reported for THC in combined dosage form with PCM and ACE. The accuracy of the both methods was evaluated by percentage recovery (by standard addition method) of all three drugs and it was in the range of $99.84-101 \%$ with values for SD and \% RSD of $<$ $2 \%[28,29]$.

A single Spectroflurometric method was reported for estimation THC in injection which is based on the oxidation of THC with cerium (IV) to produce cerium (III), whose fluorescence was monitored at $366 \mathrm{~nm}$ [30].

\section{Chromatography}

High-Performance Liquid-Chromatography (HPLC) [3154]

About Twenty four HPLC methods were reported for determination THC in combined pharmaceutical formulations. Table 2. shows the summary of the reported HPLC methods indicating the mobile phase used for determination, sample matric, $\lambda_{\max }$ and linearity $\left(\mathrm{r}^{2}\right)$.

Table 3. Summarizes the column with specifications for analysis by HPLC methods along with the conditions used such as flow rate, temperature, detector, analysis type etc.

\section{High-Performance Thin-layer Chromatography [55-63]}

Nine simple HPTLC methods have been reported for simultaneous estimation of THC in combined dosage form with ACE, DCF, DXKET, LOR, ETR and ETD. Table 4. shows the summary of the reported HPTLC methods.

\section{Estimation of THC Using Hyphenated Techniques and in Biological Matrices}

In Hyphenated techniques, Liquid-chromatography (LC), Gas-chromatography (GC) or capillary electrophoresis is linked to spectroscopic techniques, e.g. MS, FT-IR, NMR etc. resulting in new advanced techniques like CE-MS, GCMS, MS-MS, LC-MS LC-MS-MS LC-NMR etc. Such techniques provide structural information and identification of drugs and degradation compounds. Amongst these analytical techniques, LC-MS is reported to be extensively used technique. An LC-ESI-MS ${ }^{n}$ analysis is performed for forced degradation study of THC to assess its inherent chemical stability. Method reports five degradation products of THC and the degradants were characterized by MS, NMR and IR spectroscopic techniques confirming it by synthesis of degradants. The study elucidated that hydrolysis and oxidation are major degradation pathways for THC. Five degradation products were resulted and the DPs were:D1SO-(N-[1,2-dimethoxy-10methylsulphoxide-9-oxo-3-(3,4,5-trihydroxy-6 hydroxymethyltetrahydropyran-2-yloxy)-5,6,7,9-tetrahydro-benzo[a] heptalen-7-yl]-acetamide), D1SO2-(N-[1,2-dimethoxy-10methylsulphone-9-oxo-3-(3,4,5-trihydroxy-6-hydroxymethyltetrahydropyran-2-yloxy)-5,6,7,9-tetrahydro-benzo[a]heptalen7-yl]-acetamide), D2([1,2-dimethoxy-10-methylsulphanyl-9oxo-3-(3,4,5-trihydroxy-6-hydroxymethyl-tetrahydropyran2-yloxy)-5,6,7,9-tetrahydro-benzo[a]heptalen-7-yl]-amine), D3 (N-[1,2-dimethoxy-3-hydroxy-10-methylsulphanyl-9oxo-5,6,7,9-tetrahydro-benzo[a]heptalen-7-yl]-acetamide or 3-O-demethylthiocolchicine), D4 ([1,2-dimethoxy-3hydroxy-10-methylsulphanyl-9-oxo-5,6,7,9-tetrahydro-benzo [a]heptalen-7-yl]-amine or N-deacetyl-3-O-demethylthiocochicine). Products D1SO and D3 could be considered as the indicators of THC stability and they will be introduced in the development and validation of HPLC-UV stabilityindicating methods for determination of THC in drug substance and drug product [64].

Quantitative determination of drugs and their metabolites from biological matrices such as blood, plasma, serum, or urine play vital role in drug discovery and development. Chromatographic methods like HPLC or GC have been widely used for the bioanalysis of small molecules and Liquid-Chromatography coupled with Triple Quadrupole Mass Spectrometry (LC/MS/MS) is the single most commonly used technology amongst it. A highly sensitive LiquidChromatography-tandem Mass Spectrometry (LC-MS-MS) method has been illustrated for the determination of 3desmethylthiocolchicine in human plasma to evaluate the bioequivalence of thiocolchicoside after oral administration. The study divulge that thiocolchicoside is rapidly converted to 3-desmethylthiocolchicine (possibly partially in the acidic stomach juices) during absorption and during the first-pass effect through the liver [65]. A radioimmunoassay technique is also reported in literature to study the single-dose bioavailability of thiocolchicoside by oral and intramuscular route. This method report to relative bioavailability of both oral formulations was approximately $25 \%$, compared to the intramuscular formulation. An another study based on radioimmunoassay using cross-reacting colchicines- specific polyclonal antibodies and $\left[{ }^{3} \mathrm{H}\right]$ colchicines as marker is also depicted. In the study cross-reactivity tests were performed for some colchicine analogues, but not for 
Table 2. HPLC methods for Thiocolchicoside.

\begin{tabular}{|c|c|c|c|c|c|c|c|c|}
\hline $\begin{array}{l}\text { Sr. } \\
\text { No. }\end{array}$ & Name of drug & $\begin{array}{l}\text { Sample } \\
\text { matrix }\end{array}$ & Mobile phase composition & $\begin{array}{l}\text { Detection } \\
(\lambda \max ) \mathrm{nm}\end{array}$ & Linearity & $\begin{array}{l}\text { Rt } \\
\text { (in. } \text { min) }\end{array}$ & & Ref. \\
\hline \multirow{2}{*}{1} & $\mathrm{THC}+\mathrm{GF}$ & $\begin{array}{l}\text { Tablet } \\
\text { MIX-I }\end{array}$ & $\begin{array}{l}\text { Methanol : } 0.035 \mathrm{M} \text { phosphate } \\
\text { buffer }(50: 50, \mathrm{v} / \mathrm{v}) \mathrm{pH} 4.5\end{array}$ & \multirow{2}{*}{400} & \multirow{2}{*}{$\begin{array}{c}\text { THC- } 0.2-2 \mu \mathrm{g} / \mathrm{mL} \\
\text { GF and FN }-20-200 \\
\mu \mathrm{g} / \mathrm{mL}\end{array}$} & $\begin{array}{c}\text { THC- } 2.56 \\
\text { GF- } 4.5\end{array}$ & \multirow{2}{*}{$\begin{array}{l}\text { Good resolution } \\
\text { with low Rt }\end{array}$} & \multirow{2}{*}[31]{} \\
\hline & $\begin{array}{c}\mathrm{THC}+ \\
\mathrm{FN}\end{array}$ & $\begin{array}{l}\text { Tablet } \\
\text { MIX-II }\end{array}$ & $\begin{array}{l}\text { Methanol: } 0.03 \mathrm{M} \text { phosphate } \\
\text { buffer }(70: 30, \mathrm{v} / \mathrm{v}), \mathrm{pH} 4\end{array}$ & & & $\begin{array}{l}\text { THC-3.84 } \\
\text { FN-5.88 }\end{array}$ & & \\
\hline 2 & $\mathrm{THC}+\mathrm{ACE}$ & Tablets & $\begin{array}{l}\text { Acetonitrile: Water: Methanol } \\
\qquad(70: 20: 10, \mathrm{v} / \mathrm{v})\end{array}$ & 260 & $\begin{array}{l}\text { THC-4 - } 20 \mu \mathrm{g} / \mathrm{mL} \\
\text { ACE-40-200 } \mu \mathrm{g} / \mathrm{mL}\end{array}$ & $\begin{array}{l}\text { THC-3.36 } \\
\text { ACE-4.12 }\end{array}$ & $\begin{array}{l}\text { Low Rt and } \\
\text { Robust }\end{array}$ & {$[32]$} \\
\hline 3 & $\mathrm{THC}+\mathrm{ACE}$ & Tablets & $\begin{array}{l}\text { Acetonitrile: Water: } 0.025 \mathrm{M} \text { pot. } \\
\text { dihydrogen orthophosphate buffer } \\
\text { (pH adjusted to } 3.0 \text { with OPA) } \\
(70: 10: 20, \mathrm{v} / \mathrm{v})\end{array}$ & 260 & $\begin{array}{c}\text { THC-1-6 } \mu \mathrm{g} / \mathrm{mL} \\
\text { ACE-25-150 } \mu \mathrm{g} / \mathrm{mL}\end{array}$ & $\begin{array}{l}\text { THC-2.70 } \\
\text { ACE-4.76 }\end{array}$ & $\begin{array}{l}\text { Simple and } \\
\text { sensitive }\end{array}$ & {$[33]$} \\
\hline 4 & $\mathrm{THC}+\mathrm{ACE}$ & Tablets & $\begin{array}{l}\text { Phosphate buffer :Acetonitrile } \\
\qquad(40: 60 \mathrm{v} / \mathrm{v})\end{array}$ & 261 & $\begin{array}{l}\text { THC } 2-12 \mu \mathrm{g} / \mathrm{mL} \\
\text { ACE } 25-150 \mu \mathrm{g} / \mathrm{mL}\end{array}$ & $\begin{array}{l}\text { THC-2.17 } \\
\text { ACE-4.80 }\end{array}$ & $\begin{array}{l}\text { Simple mobile } \\
\text { phase }\end{array}$ & {$[34]$} \\
\hline 5 & $\mathrm{THC}+\mathrm{ACE}$ & Tablets & $\begin{array}{l}\text { Acetonitrile: buffer of } \mathrm{pH} 6 \\
(42: 58, \mathrm{v} / \mathrm{v})\end{array}$ & 261 & $\begin{array}{c}\text { ACE } 25-125 \mu \mathrm{g} / \mathrm{mL} \\
\text { THC } 1-6 \mu \mathrm{g} / \mathrm{mL}\end{array}$ & $\begin{array}{l}\text { THC-4.15 } \\
\text { ACE-4.88 }\end{array}$ & Low resolution & {$[35]$} \\
\hline 6 & $\mathrm{THC}+\mathrm{DCF}$ & Capsules & $\begin{array}{l}\text { Acetonitrile: Methanol: Water } \\
(35: 15 ; 50, \mathrm{v} / \mathrm{v}), \mathrm{pH} \text { adjusted to } \\
3.5 \text { with orthophosphoric acid. }\end{array}$ & 286 & $\begin{array}{l}\text { THC } 10-100 \mu \mathrm{g} / \mathrm{mL} \\
\text { DCF- } 20-100 \mu \mathrm{g} / \mathrm{mL}\end{array}$ & $\begin{array}{l}\text { THC-3.3 } \\
\text { DCF-4.0 }\end{array}$ & Low resolution & {$[36]$} \\
\hline 7 & $\mathrm{THC}+\mathrm{DCF}$ & Tablet & $\begin{array}{l}\text { Water (pH 9.2adjusted with di- } \\
\text { Potassium hydrogen Phosphate) } \\
(60: 40, \mathrm{v} / \mathrm{v})\end{array}$ & 223 & $\begin{array}{l}\text { THC } 50-150 \mu \mathrm{g} / \mathrm{mL} \\
\text { DCF- } 50-150 \mu \mathrm{g} / \mathrm{mL}\end{array}$ & $\begin{array}{c}\text { DCF-3.229 THC- } \\
4.999\end{array}$ & Low resolution & {$[37]$} \\
\hline 8 & $\mathrm{THC}+\mathrm{LOR}$ & Tablets & $\begin{array}{l}\text { Methanol: THF: acetate buffer } \\
\text { (60: } 10: 30, \mathrm{v} / \mathrm{v}) ; \mathrm{pH} \text { adjusted to } \\
5.5 \text { with glacial acetic acid }\end{array}$ & 250 & $\begin{array}{l}\text { LOR } 0.2 \text { to } 80 \mu \mathrm{g} / \mathrm{mL} \\
\text { THC } 0.1 \text { to } 40 \mu \mathrm{g} / \mathrm{mL}\end{array}$ & $\begin{array}{l}\text { LOR-.4.08 } \\
\text { THC- } 3.36\end{array}$ & Low resolution & {$[38]$} \\
\hline 9 & $\mathrm{THC}+\mathrm{LOR}$ & Tablet & $\begin{array}{l}\text { Methanol: Acetate buffer (PH- } \\
\text { 4.6) }: \operatorname{THF}(50: 35: 15, \mathrm{v} / \mathrm{v})\end{array}$ & 375 & $\begin{array}{c}\text { LOR }-4-100 \mu \mathrm{g} / \mathrm{mL} \\
\text { THC-2-50 } \mu \mathrm{g} / \mathrm{mL}\end{array}$ & $\begin{array}{l}\text { LOR-.400 } \\
\text { THC- } 2.92\end{array}$ & $\begin{array}{l}\text { Complex mo- } \\
\text { bile phase }\end{array}$ & {$[39]$} \\
\hline 10 & $\mathrm{THC}+\mathrm{LOR}$ & Tablet & $\begin{array}{l}\text { Ammonium Dihydrogen Phos- } \\
\text { phate buffer (pH } 7.3 \text { with TEA): } \\
\text { Methanol }(45: 55, \mathrm{v} / \mathrm{v})\end{array}$ & 290 & $\begin{array}{c}\text { LOR-0.24 - } \\
120 \mu \mathrm{g} / \mathrm{mL} \text { THC- } \\
0.23-120 \mu \mathrm{g} / \mathrm{mL}\end{array}$ & $\begin{array}{l}\text { LOR }-9.40 \\
\text { THC-2.96 }\end{array}$ & $\begin{array}{l}\text { Time consum- } \\
\text { ing }\end{array}$ & {$[40]$} \\
\hline 11 & $\mathrm{THC}+\mathrm{LOR}$ & Tablet & $\begin{array}{c}\text { Sodium Phosphate buffer( } \mathrm{pH} 6.8 \\
\text { adjusted with } \mathrm{NaOH}): \mathrm{ACN} \\
(35: 65 \% \mathrm{v} / \mathrm{v})\end{array}$ & 298 & $\begin{array}{l}\mathrm{LOR}-1-50 \mu \mathrm{g} / \mathrm{mL} \\
\mathrm{THC}-5-25 \mu \mathrm{g} / \mathrm{mL}\end{array}$ & $\begin{array}{l}\text { LOR }-4.50 \\
\text { THC }-3.40\end{array}$ & Low resolution & {$[41]$} \\
\hline 12 & $\mathrm{THC}+\mathrm{KET}$ & Tablet & $\begin{array}{l}\text { Acetonitrile: Water: Phosphate } \\
\text { buffer }(\mathrm{pH} 3.0)(60: 30: 10, \mathrm{v} / \mathrm{v})\end{array}$ & 260 & 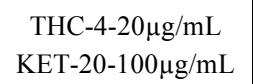 & $\begin{array}{l}\text { THC- } 2.70 \\
\text { KET- } 4.90\end{array}$ & Low resolution & {$[42]$} \\
\hline 13 & THC+KET & Tablet & $\begin{array}{l}\text { Acetonitrile: Water } \\
(60: 40, \mathrm{v} / \mathrm{v})\end{array}$ & 300 & $\begin{array}{l}\text { KET-80-120 } \mu \mathrm{g} / \mathrm{mL} \\
\text { THC-6.4-9.6 } \mu \mathrm{g} / \mathrm{mL}\end{array}$ & $\begin{array}{r}\text { THC }-3.7 \pm 0.1 \\
\text { KET }-7.90 \pm 0.1\end{array}$ & $\begin{array}{l}\text { Economical and } \\
\text { good resolution }\end{array}$ & {$[43]$} \\
\hline 14 & THC+DXKET & Tablet & $\begin{array}{l}\text { Methanol: Sodium acetate buffer } \\
\text { (pH } 5 \text { with Glacial acetic acid) } \\
(70: 30, v / v)\end{array}$ & 265 & $\begin{array}{c}\text { DXKET-5-30 } \mu \mathrm{g} / \mathrm{mL} \\
\text { THC-1 }-10 \mu \mathrm{g} / \mathrm{mL}\end{array}$ & $\begin{array}{c}\text { THC-3.0133 } \\
\text { DXKET } \\
6.013\end{array}$ & $\begin{array}{l}\text { Economical } \\
\text { And well sepa- } \\
\text { ration }\end{array}$ & [44] \\
\hline 15 & THC+DXKET & Tablet & $\begin{array}{c}\text { Methanol: Phosphate buffer } \\
\text { (pH adjusted to } 4.5 \text { with OPA) } \\
(65: 35 \mathrm{v} / \mathrm{v})\end{array}$ & 260 & $\begin{array}{c}\text { THC } 4-24 \mu \mathrm{g} / \mathrm{mL} \\
\text { DXKET-5-30 } \\
\mu \mathrm{g} / \mathrm{mL}\end{array}$ & $\begin{array}{l}\text { THC-3.02 } \\
\text { DXK } 8.91\end{array}$ & $\begin{array}{l}\text { Economical and } \\
\text { well separation }\end{array}$ & {$[45]$} \\
\hline 16 & THC+ETR & Tablet & $\begin{array}{l}\text { Trifluoroacetic acid buffer }(\mathrm{pH} \\
2.6) \text { : Acetonitrile }(75: 25, \mathrm{v} / \mathrm{v})\end{array}$ & 220 & $\begin{array}{l}\text { ETR } 20-160 \mu \mathrm{g} / \mathrm{mL} \\
\text { THC } 2-16 \mu \mathrm{g} / \mathrm{mL}\end{array}$ & ETR-6.6 THC-3.1 & Simple & {$[46]$} \\
\hline 17 & $\mathrm{THC}+\mathrm{ETR}$ & Tablet & $\begin{array}{c}1 \mathrm{~mL} \text { TFA in } 2 \text { liter milli-Q } \\
\text { water) and Acetonitrile (75:25 } \\
\mathrm{v} / \mathrm{v})\end{array}$ & 258 & $\begin{array}{l}\text { ETR } 1.598-90 \mu \mathrm{g} / \mathrm{mL} \\
\text { THC } 4.95-12 \mu \mathrm{g} / \mathrm{mL}\end{array}$ & $\begin{array}{l}\text { THC-3.37 } \\
\text { ETR-8.62 }\end{array}$ & Simple & {$[47]$} \\
\hline
\end{tabular}


(Table 2) contd....

\begin{tabular}{|c|c|c|c|c|c|c|c|c|}
\hline $\begin{array}{l}\text { Sr. } \\
\text { No. }\end{array}$ & Name of drug & $\begin{array}{l}\text { Sample } \\
\text { matrix }\end{array}$ & Mobile phase composition & $\begin{array}{l}\text { Detection } \\
(\lambda \max ) \mathrm{nm}\end{array}$ & Linearity & $\begin{array}{c}\text { Rt } \\
\text { (in. } \text { min) }\end{array}$ & & Ref. \\
\hline 18 & THC+ETR & Tablet & $\begin{array}{c}\text { Phosphate buffer } \\
\text { (PH 6, adjusted with orthophos- } \\
\text { phoric acid) and Methanol (30:70 } \\
\text { v/v) }\end{array}$ & 255 & $\begin{array}{l}\text { ETR } 40-80 \mu \mathrm{g} / \mathrm{mL} \\
\text { THC } 2-6 \mu \mathrm{g} / \mathrm{mL}\end{array}$ & $\begin{array}{l}\text { THC-2.50 ETR- } \\
4.60\end{array}$ & Robust & [48] \\
\hline 19 & THC+ETD & Tablet & $\begin{array}{l}\text { Methanol and Phosphate buffer } \\
\qquad \mathrm{pH} 6,(85: 15 \mathrm{v} / \mathrm{v})\end{array}$ & 259 & $\begin{array}{l}\text { ETD } 16-96 \mu \mathrm{g} / \mathrm{mL} \\
\text { THC } 4-24 \mu \mathrm{g} / \mathrm{mL}\end{array}$ & $\begin{array}{l}\text { ETD4.39 } \pm 0.10 \\
\text { THC3.52 } \pm 0.10\end{array}$ & $\begin{array}{l}\text { Simple mobile } \\
\text { phase but less } \\
\text { separation }\end{array}$ & [49] \\
\hline 20 & THC+ETD & Tablet & $\begin{array}{l}\text { Acetonitrile: } 20 \mathrm{mM} \text { potassium } \\
\text { dihydrogen phosphate buffer } \\
\qquad(65: 35 \mathrm{v} / \mathrm{v})\end{array}$ & 257 & $\begin{array}{l}\text { ETD } 25-150 \mu \mathrm{g} / \mathrm{mL} \\
\text { THC } 0.5-10 \mu \mathrm{g} / \mathrm{mL}\end{array}$ & $\begin{array}{l}\text { THC-2.240 } \\
\text { ETD-7.141 }\end{array}$ & $\begin{array}{c}\text { Robust, } \\
\text { Good resolution }\end{array}$ & {$[50]$} \\
\hline 21 & THC+ETD & Tablet & $\begin{array}{l}\text { Acetonitrile: Potassium dihydro- } \\
\text { gen phosphate buffer }(\mathrm{pH} 3.0) \\
(50: 50, \mathrm{v} / \mathrm{v})\end{array}$ & 255 & $\begin{array}{l}\text { ETD } 100-600 \mu \mathrm{g} / \mathrm{mL} \\
\text { THC } 1-6 \mu \mathrm{g} / \mathrm{mL}\end{array}$ & ETD-4.27 THC-2.6 & $\begin{array}{l}\text { high linearity } \\
\text { values }\end{array}$ & [51] \\
\hline 23 & $\begin{array}{l}\mathrm{THC}+ \\
\mathrm{ACE}+ \\
\mathrm{PCM}\end{array}$ & Tablet & Acetonitrile: Water $(30: 70, \mathrm{v} / \mathrm{v})$ & 263 & $\begin{array}{c}\text { PCM- } 50-175 \mu \mathrm{g} / \mathrm{mL} \\
\text { ACE- } 10-35 \mu \mathrm{g} / \mathrm{mL} \\
\text { THC- } 0.40-1.4 \\
\mu \mathrm{g} / \mathrm{mL}\end{array}$ & $\begin{array}{l}\text { PCM- } 2.51 \\
\text { THC-3.55 } \\
\text { ACE }-5.20\end{array}$ & $\begin{array}{l}\text { Simple and } \\
\text { economical }\end{array}$ & [53] \\
\hline 24 & $\begin{array}{l}\mathrm{THC}+ \\
\mathrm{ACE}+ \\
\mathrm{PCM}\end{array}$ & & $\begin{array}{l}\text { Buffer of } \mathrm{pH} 6.5 \text { and Acetonitrile } \\
\quad \text { in Gradient elution. }\end{array}$ & 300 & $\begin{array}{c}\text { PCM } 1250-3750 \\
\mu \mathrm{g} / \mathrm{mL} \\
\text { THC } 20-60 \mu \mathrm{g} / \mathrm{mL} \\
\text { ACE } 250-750 \mu \mathrm{g} / \\
\mathrm{mL}\end{array}$ & $\begin{array}{l}\text { PCM- } 2.70 \\
\text { THC-3.95 } \\
\text { ACE }-9.91\end{array}$ & Well resolution & [54] \\
\hline
\end{tabular}

3-desmethylthiocolchicine (aglycone part of thiocolchicoside) [66]. Similarly, a capillary gas chromatography-mass spectrometry (GC-MS) method is presented for THC following enzymatic hydrolysis of thiocolchicoside to its aglycone (3-demethylthiocolchicine). The study reports oral bioavailability of the capsule formulation was $1.06+/-0.39$ relative to the tablet formulation [67].

A bioequivalence study has been reported for fixed dose combination of thiocolchicoside and lornoxicam in twenty four healthy male volunteers using liquid chromatographytandem mass spectrometry (LC-MS-MS) method [68]. Similarly, a bioanalytical method is also reported for simultaneous determination of THC and lornoxicam from pharmaceutical formulation in human plasma which uses an isocratic RP-HPLC method [69].

A bioanalytical method for the simultaneous estimation of active metabolite of thiocolchicoside (3demythylthiocolchicine) and diclofenac in human plasma by means of LC-MS/MS is also reported. The method employed Reversed-Phase phenomenex gemini $\mathrm{C}_{18}$ column with a mobile phase containing Methanol: Water (containing 0.2\% formic acid) $(9: 1, v / v)$. The calibration curves were linear over the range of 1 to $50 \mathrm{ng} / \mathrm{mL}$ for 3demythylthiocolchicine and 25 to $2500 \mathrm{ng} / \mathrm{mL}$ for DCF with the lower limit of quantification validated at $0.5 \mathrm{ng} / \mathrm{mL}$ for 3-demythylthiocolchicine and $5 \mathrm{ng} / \mathrm{mL}$ for DCF [70].

One UV-spectrophotometric method was found for simultaneous estimation of THC with ETD using methanol as solvent by simultaneous equation and Q-absorbance ratio method in tablets and in spiked human urine. The authors have also performed force degradation study for both drugs and reported that THC is only subjected to alkaline hydrolysis indicating change in $\lambda_{\max }$ of THC. The authors also compared their proposed method with reference method from literature and concluded that, the present method is better than the existing reference method because $0.1 \mathrm{~N} \mathrm{NaOH}$ is used in reference method which can be responsible for degradation of THC in alkaline medium and interfere with the $\lambda_{\max }$ of THC [71].

\section{Stability-Indicating Methods (SIM) for Determination of THC [72-83]}

About thirteen stability-indicating methods have been reported for determination of THC in bulk substances and pharmaceutical formulations using different analytical techniques. Among it, three methods are for estimation of THC alone and ten of them described for stability-indicating nature of method for combined dosage form. Maximum of 14$15 \%$ were reported using HPLC, 3-4 \% were based on HPTLC and $1-2 \%$ were LC/MS methods. Table 5. shows the reported stability-indicating methods for THC; illustrating sample matrix, $\lambda_{\max }$, linearity range and retention time/factor.

\section{Official Methods for Analysis of Thiocolchicoside [84]}

THC is official drug in Indian Pharmacopoeia 2010. Two HPLC methods are described for assay of THC from pharmaceutical formulations and its related substances. 
Table 3. HPLC chromatographic columns and optimized analytical parameters.

\begin{tabular}{|c|c|c|c|c|c|c|c|c|c|}
\hline $\begin{array}{l}\text { Sr. } \\
\text { No. }\end{array}$ & Name of drug & Column & $\begin{array}{l}\text { Internal diameter and } \\
\text { Partical Size }\end{array}$ & Temp. & Detector & Flow rate & $\begin{array}{l}\text { Mode of } \\
\text { analysis }\end{array}$ & Diluents & Ref. \\
\hline \multirow{2}{*}{1} & $\mathrm{THC}+\mathrm{GF}$ & \multirow{2}{*}{$\begin{array}{c}\mathrm{C} 18 \\
\text { (Waters symmetry) }\end{array}$} & \multirow{2}{*}{$\begin{array}{l}\text { i.d. }-250 \times 4.6 \mathrm{~mm} \\
5-\mu \mathrm{m}\end{array}$} & \multirow{2}{*}{ RT } & \multirow{2}{*}{ UV detector } & \multirow{2}{*}{$1 \mathrm{~mL} / \mathrm{min}$} & \multirow{2}{*}{ Isocratic } & \multirow{2}{*}{ Methanol } & \multirow{2}{*}[31]{} \\
\hline & $\mathrm{THC}+\mathrm{FN}$ & & & & & & & & \\
\hline 2 & $\mathrm{THC}+\mathrm{ACE}$ & C18 (Intersil) & $\begin{array}{c}250 \mathrm{~mm} \times 4.6 \mathrm{~mm}, 20- \\
\mu \mathrm{m}\end{array}$ & RT & $\begin{array}{l}\text { Variable wave- } \\
\text { length detector }\end{array}$ & $1 \mathrm{~mL} / \mathrm{min}$ & Gradient & Methanol & {$[32]$} \\
\hline 3 & $\mathrm{THC}+\mathrm{ACE}$ & C18(Thermo) & i.d-250x4.6 mm;5- $\mu \mathrm{m}$ & Ambient & UV detector & $1 \mathrm{~mL} / \mathrm{min}$ & Isocratic & M.P & {$[33]$} \\
\hline 4 & $\mathrm{THC}+\mathrm{ACE}$ & $\begin{array}{c}\mathrm{C} 18 \\
\text { (Waters symmetry) }\end{array}$ & $\begin{array}{l}\text { i.d. }-150 \times 4.6 \mathrm{~mm} ; \\
5-\mu \mathrm{m}\end{array}$ & RT & UV detector & $1 \mathrm{~mL} / \mathrm{min}$ & Isocratic & Methanol & [34] \\
\hline 5 & $\mathrm{THC}+\mathrm{ACE}$ & $\begin{array}{c}\mathrm{C} 18 \\
\text { (Thermo Hypersil } \\
\text { BDS) }\end{array}$ & i.d.-250X4.6 mm; $5 \mu \mathrm{m}$ & RT & $\begin{array}{l}\text { diode array detec- } \\
\text { tor }\end{array}$ & $0.6 \mathrm{~mL} / \mathrm{min}$ & Isocratic & MP & {$[35]$} \\
\hline 6 & $\mathrm{THC}+\mathrm{DCF}$ & C18 (Intersil) & i.d. $-250 \times 4.6 \mathrm{~mm} ; 5 \mu \mathrm{m}$ & RT & $\begin{array}{l}\text { Variable wave- } \\
\text { length detector }\end{array}$ & $1 \mathrm{~mL} / \mathrm{min}$ & Gradient & Water & {$[36]$} \\
\hline 7 & $\mathrm{THC}+\mathrm{DCF}$ & $\begin{array}{l}\text { C18 (Waters } \\
\text { Symmetry) }\end{array}$ & $\begin{array}{l}\text { i.d. } 250 \mathrm{X} 4.6 \\
; 5 \mu \mathrm{m}\end{array}$ & $30^{\circ} \mathrm{C}$ & PDA detector & $1 \mathrm{~mL} / \mathrm{min}$ & Isocratic & M.P & {$[37]$} \\
\hline 8 & $\mathrm{THC}+\mathrm{LOR}$ & $\begin{array}{l}\text { C18 (Waters } \\
\text { Symmetry) }\end{array}$ & $\begin{array}{c}\text { i.d. }-250 \mathrm{~mm} \times 4.6 \\
\mathrm{~mm} ; 5.0 \mu \mathrm{m}\end{array}$ & $50{ }^{0} \mathrm{C}$ & PDA detector & $0.75 \mathrm{~mL} / \mathrm{min}$ & Isocratic & MP & {$[38]$} \\
\hline 9 & $\mathrm{THC}+\mathrm{LOR}$ & C18(Varian) & $\begin{array}{c}\text { i.d. }-250 \mathrm{~mm} \times 4.6 \mathrm{~mm} \text {; } \\
5 \mu \mathrm{m}\end{array}$ & $25 \pm 3^{0} \mathrm{C}$ & UV detector & $0.5 \mathrm{~mL} / \mathrm{min}$ & isocratic & Methanol & [39] \\
\hline 10 & $\mathrm{THC}+\mathrm{LOR}$ & $\begin{array}{c}\mathrm{C} 18 \\
\text { (Inertsil ODS 3V) }\end{array}$ & i.d. $-250 \times 4.6 \mathrm{~mm} ; 5 \mu \mathrm{m}$ & $30^{\circ} \mathrm{C}$ & PDA detector & $1.5 \mathrm{~mL} / \mathrm{min}$ & isocratic & MP & {$[40]$} \\
\hline 11 & $\mathrm{THC}+\mathrm{LOR}$ & $\mathrm{C} 8(\mathrm{X}$ terra $)$ & i.d. $-4.6 \times 250 \mathrm{~mm} ; 5 \mu \mathrm{m}$, & Ambient & UV detector & $1 \mathrm{~mL} / \mathrm{min}$ & isocratic & MP & {$[41]$} \\
\hline 12 & $\mathrm{THC}+\mathrm{KET}$ & $\begin{array}{c}\text { C18 } \\
\text { (Thermo scientific) }\end{array}$ & i.d. $-250 \times 4.6 \mathrm{~mm} ; 5 \mu \mathrm{m}$ & $25 \pm 1{ }^{\circ} \mathrm{C}$ & UV detector & $1 \mathrm{~mL} / \mathrm{min}$ & Isocratic & MP & {$[42]$} \\
\hline 13 & $\begin{array}{l}\text { THC+ } \\
\text { KET }\end{array}$ & $\mathrm{C} 18$ & i.d. $-150 \times 4.6 \mathrm{~mm} ; 5 \mu \mathrm{m}$ & RT & UV detector & $1 \mathrm{~mL} / \mathrm{min}$ & Isocratic & MP & {$[43]$} \\
\hline 14 & $\begin{array}{c}\text { THC+ } \\
\text { DXKET }\end{array}$ & $\begin{array}{l}\text { C18 (HS, } \\
\text { HiQ sil) }\end{array}$ & $\begin{array}{l}\text { i.d.- } 250 \times 4.6 \\
\mathrm{~mm} ; 5 \mu \mathrm{m}\end{array}$ & Ambient & PDA detector & $1 \mathrm{~mL} / \mathrm{min}$ & Isocratic & MP & [44] \\
\hline 15 & THC+DXKET & $\begin{array}{c}\text { RP-18e } \\
\text { (Purosphere STAR) }\end{array}$ & i.d. $-250 \times 4 \mathrm{~mm} ; 5 \mu \mathrm{m}$ & RT & UV detector & $1.0 \mathrm{~mL} / \mathrm{min}$ & Isocratic & MP & {$[45]$} \\
\hline 16 & $\mathrm{THC}+\mathrm{ETR}$ & $\begin{array}{c}\text { C-18 } \\
\text { (BDS Hypersil) }\end{array}$ & i.d.-250 X4.6 mm; 5- $\mu \mathrm{m}$. & Ambient & UV detector & $1.5 \mathrm{~mL} / \mathrm{min}$ & Isocratic & MP & {$[46]$} \\
\hline 17 & $\mathrm{THC}+\mathrm{ETR}$ & $\begin{array}{c}\text { C18 } \\
\text { (RP-select B Li- } \\
\text { chrospher) }\end{array}$ & i.d. $-250 \times 4.6 \mathrm{~mm} ; 5 \mu \mathrm{m}$ & --- & PDA & $1.5 \mathrm{~mL} / \mathrm{min}$ & Isocratic & MP & {$[47]$} \\
\hline 18 & $\mathrm{THC}+\mathrm{ETR}$ & $\begin{array}{c}\text { C18 (InertSil ODS- } \\
3 \text { ) }\end{array}$ & i.d. $-250 \times 4.6 \mathrm{~mm} ; 5 \mu \mathrm{m}$ & -- & UV detector & $1.2 \mathrm{~mL} / \mathrm{min}$ & Isocratic & MP & {$[48]$} \\
\hline 19 & $\mathrm{THC}+\mathrm{ETD}$ & C-18 (Phenomenex) & $\begin{array}{l}\text { i.d. }-250 \mathrm{~mm} \times 4.60 \mathrm{~mm} \text {; } \\
5 \mu \mathrm{m}\end{array}$ & -- & UV detector & $0.8 \mathrm{~mL} / \mathrm{min}$ & Isocratic & MP & [49] \\
\hline 20 & $\mathrm{THC}+\mathrm{ETD}$ & C18 (HiQ sil HS) & $\begin{array}{l}\text { i.d- } 250 \times 4.6 \\
\mathrm{~mm} ; 5 \mu \mathrm{m}\end{array}$ & Ambient & UV detector & $1 \mathrm{~mL} / \mathrm{min}$ & Isocratic & MP & {$[50]$} \\
\hline 21 & THC+ETD & C18 (Symmetry) & i.d.- $150 X 4.6 \mathrm{~mm} ; 5 \mu \mathrm{m}$ & $25 \pm 1^{0} \mathrm{C}$ & UV detector & $1.0 \mathrm{~mL} / \mathrm{min}$ & Isocratic & Methanol & {$[51]$} \\
\hline 22 & $\begin{array}{l}\mathrm{THC}+ \\
\mathrm{PCM}\end{array}$ & C18 (BDS hypersil) & $\begin{array}{c}\text { i.d. }-250 \mathrm{~mm} \times 4.6 \mathrm{~mm}, \\
5 \mu \mathrm{m}\end{array}$ & Ambient & UV detector & $1.0 \mathrm{~mL} / \mathrm{min}$ & Isocratic & MP & {$[52]$} \\
\hline 23 & $\mathrm{THC}+\mathrm{ACE}+\mathrm{PCM}$ & C18 (HiQ Sil) & $\begin{array}{c}\text { i.d. }-250 \mathrm{~mm} \times 4.6 \mathrm{~mm}, \\
5.0 \mu \mathrm{m}\end{array}$ & Ambient & UV detector & $1.0 \mathrm{~mL} / \mathrm{min}$ & Isocratic & Methanol & {$[53]$} \\
\hline 24 & $\begin{array}{c}\mathrm{THC}+ \\
\mathrm{ACE}+ \\
\mathrm{PCM}\end{array}$ & C18 (inertsil ODS) & $\begin{array}{l}\text { i.d- } 150 \times 4.6 \mathrm{~mm} \\
; 5 \mu \mathrm{m}\end{array}$ & Ambient & PDA detector & $1.0 \mathrm{~mL} / \mathrm{min}$ & Gradient & MP & {$[54]$} \\
\hline
\end{tabular}


Table 4. HPTLC methods for determination of thiocolchicoside.

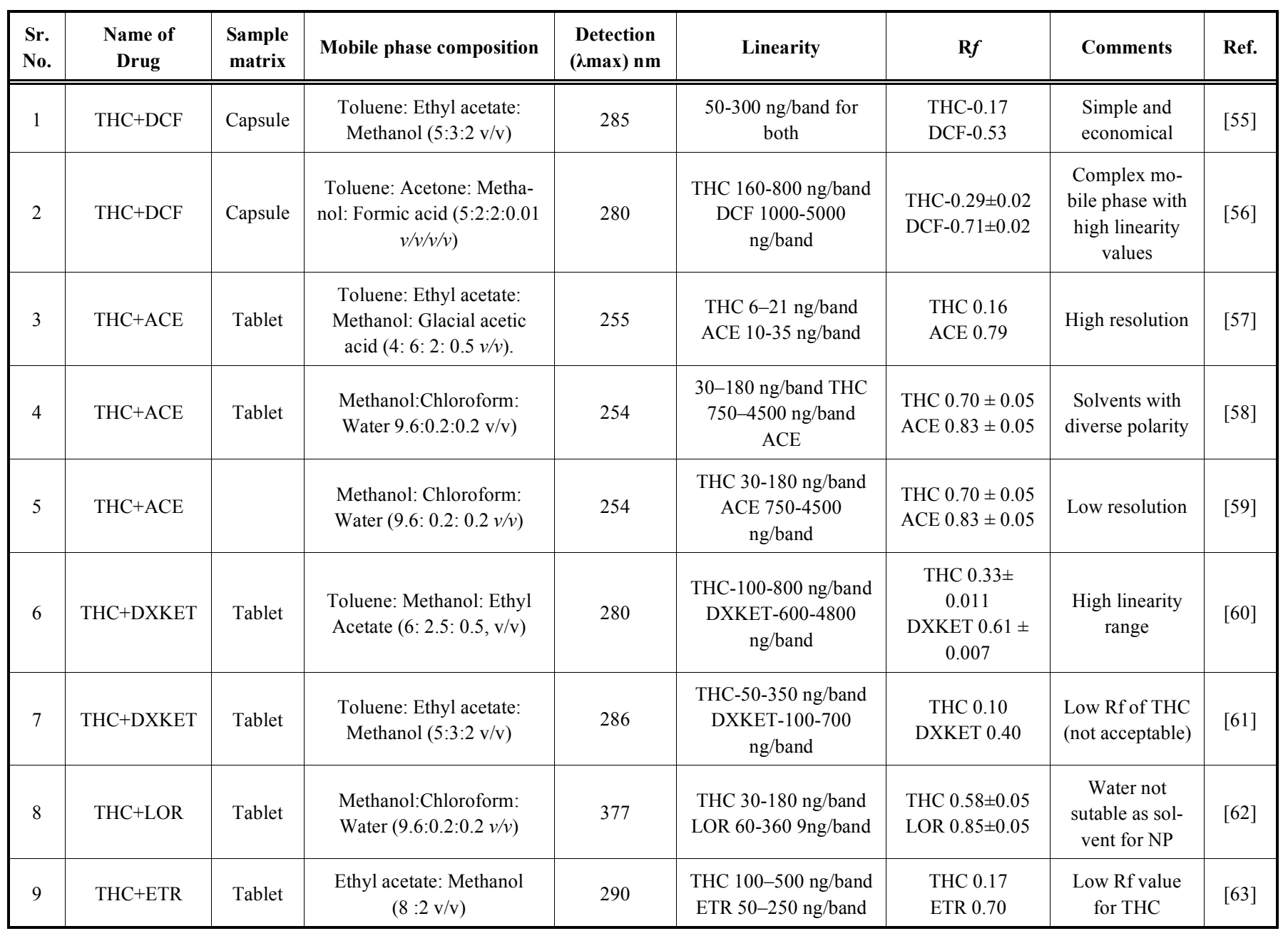

Table 5. Stability-indicating HPLC and HPTLC methods for determination of thiocolchicoside.

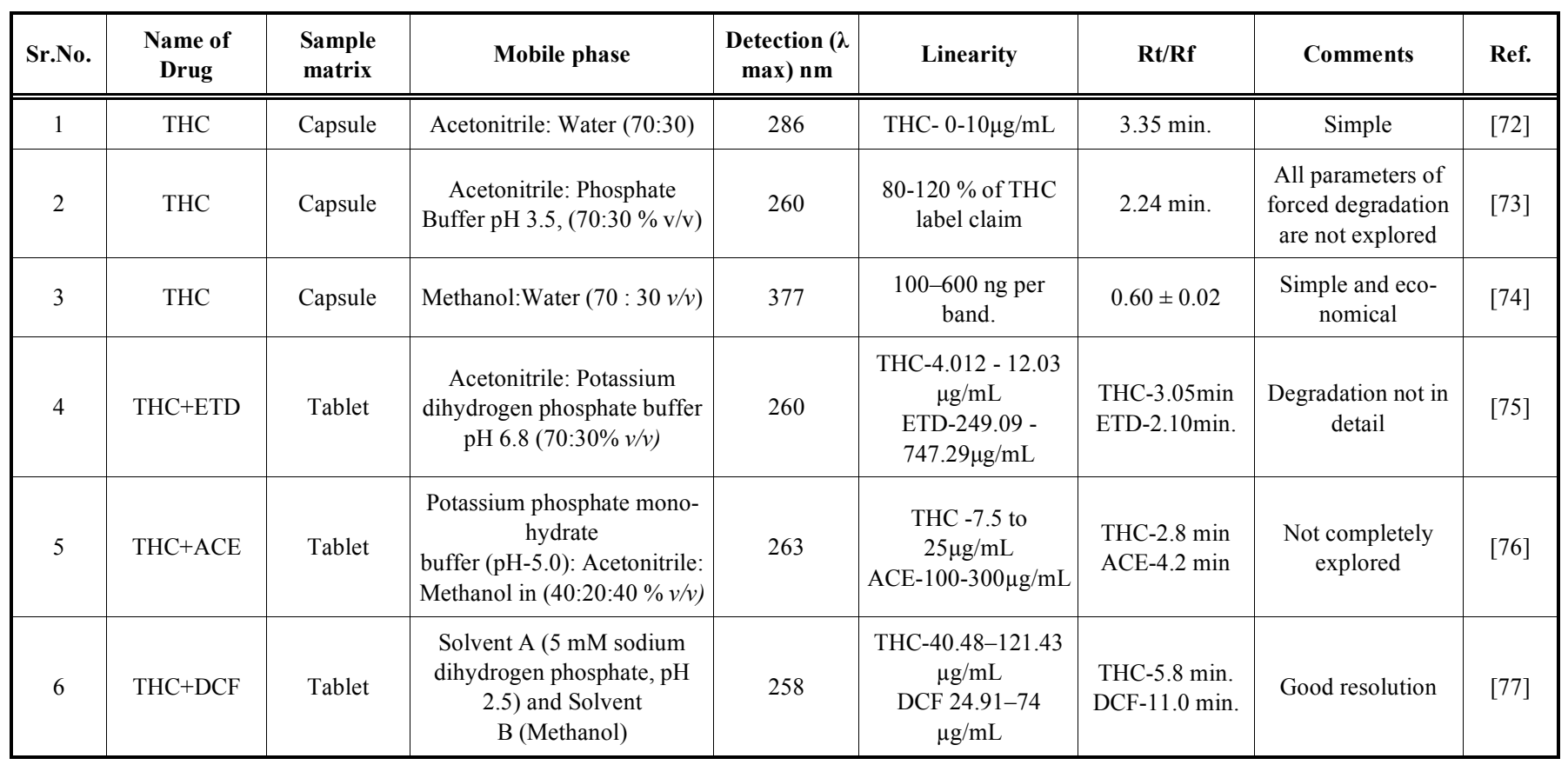


(Table 5) contd...

\begin{tabular}{|c|c|c|c|c|c|c|c|c|}
\hline Sr.No. & $\begin{array}{l}\text { Name of } \\
\text { Drug }\end{array}$ & $\begin{array}{l}\text { Sample } \\
\text { matrix }\end{array}$ & Mobile phase & $\begin{array}{l}\text { Detection }(\lambda \\
\max ) \mathbf{n m}\end{array}$ & Linearity & $\mathbf{R t} / \mathbf{R f}$ & Comments & Ref. \\
\hline 7 & $\mathrm{THC}+\mathrm{DCF}$ & Tablet & $\begin{array}{c}\text { Methanol: Acetonitrile : } \\
\text { Phosphate buffer }(40: 20: 40 \\
v / v \text { at } \mathrm{pH} 5.0)\end{array}$ & 263 & $\begin{array}{r}\mathrm{THC}-7.5-25 \mu \mathrm{g} / \mathrm{mL} \\
\mathrm{DCF}-100-300 \mu \mathrm{g} / \mathrm{mL}\end{array}$ & $\begin{array}{l}\mathrm{THC}-2.8 \mathrm{~min} \\
\mathrm{ACE}-4.2 \mathrm{~min}\end{array}$ & $\begin{array}{l}\text { Separation not } \\
\text { suitable in case of } \\
\text { impurities }\end{array}$ & [78] \\
\hline 8 & $\mathrm{THC}+\mathrm{ACE}$ & Tablet & $\begin{array}{l}\text { Methanol: Acetonitrile: THF: } \\
\text { Acetate buffer (56:4:10:30 } \\
v / v) \text { pH adjusted to } 6.5 \text { with } \\
\text { Acetic acid }\end{array}$ & 312 & $\begin{array}{c}\text { THC-0.4- } 24 \mu \mathrm{g} / \mathrm{mL} \\
\text { ACE-10 -600 } \\
\mu \mathrm{g} / \mathrm{ML}\end{array}$ & $\begin{array}{l}\text { THC- } 4.7 \mathrm{~min} . \\
\text { ACE- } 6.3 \mathrm{~min} .\end{array}$ & $\begin{array}{l}\text { Complex mobile } \\
\text { phase }\end{array}$ & [79] \\
\hline 9 & $\mathrm{THC}+\mathrm{ACE}$ & Tablet & $\begin{array}{l}\text { (A) } 10 \mathrm{mM} \text { Ammonium } \\
\text { acetate pH } 5.00 \text { buffer and } \\
\text { (B) Acetonitrile: Water } \\
(70: 30 \mathrm{v} / \mathrm{v})\end{array}$ & 265 & $\begin{array}{c}\text { ACF-80- } \\
280 \mu \mathrm{g} / \mathrm{mL} \\
\mathrm{THC}-6.4- \\
22.4 \mu \mathrm{g} / \mathrm{mL}\end{array}$ & $\begin{array}{l}\text { THC-13.29min } \\
\text { ACF-2.20 } \mathrm{min}\end{array}$ & Higher Rt & [80] \\
\hline 10 & $\mathrm{THC}+\mathrm{ACE}$ & Tablet & $\begin{array}{l}5 \% \text { ammonium acetate buffer } \\
\text { and methanol }(40: 60 v / v) \mathrm{pH} \\
5 \text { with OPA }\end{array}$ & 276 & $\begin{array}{c}\text { THC-4.8 -7.2 } \mu \mathrm{g} / \mathrm{mL} \\
\text { ACE-63.8 }-96 \\
\mu \mathrm{g} / \mathrm{mL}\end{array}$ & $\begin{array}{l}\text { THC-0.697 min. } \\
\text { ACE-1.125 min. }\end{array}$ & Very low Rt & [81] \\
\hline 11 & $\begin{array}{l}\text { THC+ } \\
\text { KET }\end{array}$ & Tablet & $\begin{array}{l}\text { Methanol: Toluene: Benzene } \\
\qquad(2.5: 3.5: 4 \mathrm{v} / \mathrm{v})\end{array}$ & 260 & $\begin{array}{l}\text { 125-750 ng/band } \\
\mathrm{THC} \\
1000-6000 \mathrm{ng} / \mathrm{band} \\
\mathrm{KET}\end{array}$ & $\begin{array}{l}\text { THC } 0.35 \text { and } \\
\text { KET } 0.65 \text { min. }\end{array}$ & $\begin{array}{l}\text { Well resolved } \\
\text { components }\end{array}$ & [82] \\
\hline 12 & $\begin{array}{l}\mathrm{THC}+\mathrm{PCM}+ \\
\mathrm{DCF}\end{array}$ & Capsule & $\begin{array}{c}\text { Acetonitrile: Phosphate } \\
\text { buffer adjusted pH } 3 \text { with } \\
\text { OPA }\end{array}$ & 228 & $\begin{array}{l}100-500 \mu \mathrm{g} / \mathrm{mL} \\
\text { PCM, THC and } \\
\text { DCF }\end{array}$ & $\begin{array}{c}\text { PCM -5.3;THC- } \\
9.61 ; \mathrm{DCF}- \\
21.47\end{array}$ & $\begin{array}{l}\text { Economical but not } \\
\text { suitable as stability } \\
\text { indicating }\end{array}$ & [83] \\
\hline
\end{tabular}

\section{CONCLUSION}

The present review epitomizes numerous analytical methods applied for the determination of THC. A great number of studies including UV/Vis-Spectrophotometry, Spectrofluorimetry, HPLC, HPTLC, LC-ESI-MS, LC-MS, GC-MS etc. were reported for analysis of thiocolchicoside in bulk and in its combined pharmaceutical formulations as well as in plasma. It has been found that LiquidChromatography with UV-detection is the most studied for the determination of THC in bulk as well as pharmaceutical dosage forms while LC-MS and LC-MS/MS are the widely used for its estimation from plasma and other biological fluids to determine its pharmacokinetics as well as for bioavailability and bioequivalence studies. Few chromatographic methods like HPTLC and GC-MS are also published in literature. Certain Spectrophotometric methods in UV-Visible as well as fluorimetry are most often used for quantification of THC.

\section{ABBREVIATIONS}

$\begin{array}{ll}\mathrm{ACN} & =\text { Acetonitrile } \\ \mathrm{ACE} & =\text { Aceclofenac } \\ \mathrm{CE} & =\text { Capillary Electrophoresis } \\ \mathrm{DCFS} & =\text { Diclofenac Sodium } \\ \mathrm{DCFP} & =\text { Degradation products } \\ \mathrm{DPs} & =\text { Dexketoprofen } \\ \text { DXKET } & \text { Electron Spray Ionization Mass Spectrome- } \\ \text { ESI-MS } & \text { try } \\ \text { ETD } & =\text { Etodolac }\end{array}$

\begin{tabular}{|c|c|c|}
\hline ETR & $=$ & Etoricoxib \\
\hline $\mathrm{FN}$ & $=$ & Floctafenine \\
\hline $\mathrm{GC}$ & $=$ & Gas Chromatography \\
\hline GC-MS & $=$ & Gas Chromatography- Mass Spectroscopy \\
\hline GF & $=$ & Glafenine \\
\hline HPLC & $=$ & High Performance Liquid Chromatography \\
\hline HPTLC & $=$ & $\begin{array}{l}\text { High Performance Thin Layer Chromatogra- } \\
\text { phy }\end{array}$ \\
\hline IM & $=$ & Intra-muscular \\
\hline IR & $=$ & Infrared \\
\hline KET & $=$ & Ketoprofen \\
\hline LBP & $=$ & Low Back Pain \\
\hline $\mathrm{LC}$ & $=$ & Liquid Chromatography \\
\hline LOD & $=$ & Limit of Detection \\
\hline LOQ & $=$ & Limit of Quantitation \\
\hline LOR & $=$ & Lornoxicam \\
\hline M & $=$ & concentration $(\mathrm{mol} / \mathrm{L})$ \\
\hline MP & $=$ & Mobile Phase \\
\hline MS & $=$ & Mass Spectrometry \\
\hline $\mathrm{nm}$ & $=$ & nanometer \\
\hline NMR & $=$ & Nuclear Magnetic Resonance \\
\hline NSAIDs & $=$ & Non-Steroidal Anti-inflammatory Drugs \\
\hline OPA & $=$ & Orthophosphoric Acid \\
\hline $\mathrm{PCM}$ & $=$ & Paracetamol \\
\hline
\end{tabular}




$\begin{array}{ll}\text { RP-HPLC } & \begin{array}{l}\text { Reversed Phase-High Performance Liquid } \\ \text { Chromatography }\end{array} \\ \text { R.S.D. } & =\text { Relative Standard Deviation } \\ \text { TEA } & =\text { Triethylamine } \\ \text { TFA } & =\text { Trifluoroacetic Acid } \\ \text { THC } & =\text { Thiocolchicoside } \\ \text { TLC } & =\text { Thin Layer Chromatography } \\ \text { UV-Vis } & =\text { Ultraviolet-Visible }\end{array}$

\section{CONFLICT OF INTEREST}

The authors confirm that this article content has no conflict of interest.

\section{ACKNOWLEDGEMENTS}

The authors are thankful to Dr. S.J. Surana, Principal R. C. Patel Institute of Pharmaceutical Education and Research for providing necessary facilities.

\section{REFERENCES}

[1] Jana S, Shekhawat GS. Critical review on medicinally potent plant species: Gloriosa superb. Fitoterapia 2011; 82: 293-301.

[2] Trellua M, Filali-Ansary A, Francon D, Adam R, Luel PL. New metabolic and pharmacokinetic characteristics of THC and its active metabolite in healthy humans. Fund Clin Pharm 2004; 18: 493501.

[3] Janbroers JM. Review of the toxicology, pharmacodynamics and pharmacokinetics of THC, a GABA-agonist muscle relaxant with anti-inflammatory and analgesic actions. Acta Therap 1987; 13: 221-7.

[4] Central Drugs Standard Control Organization. List of drug approved for marketing in India - Year 2008. Available at: http://cdsco.nic.in/listofdrugapprovedmain.html

[5] The Merck Index, $14^{\text {th }}$ ed., Merck and Co. Inc, 2009.

[6] Carta M, Murru L, Botta P, et al. The muscle relaxant thiocolchicoside is an antagonist of GABA-A receptor function in the central nervous system. Neuropharmacology 2006; 51(4): 805-15.

[7] Kamath A. Thiocolchicoside: a review. DHR Int J Med Sci 2013; 4(2): Available online: http://www.doublehelixresearch.com/ DHRIJMS

[8] Thiocolchicoside - Amended product information. Accessed 05 Nov. 2014. www.ema.europa.eu/docs/en.../Thiocolchicoside.../ WC500155449.pdf

[9] European Medicines Agency recommends restricting use of thiocolchicoside by mouth or injectionEMA/706409/2013. Available at: www.ema.europa.eu/docs/en GB/document library/Press release/2013/11/WC500155448.pdf .

[10] Gianpietro S, Pierluigi De R, Ombretta M, Giovanni AD, Giovanni AC, Giulio R. Focal and secondarily generalised convulsive status epilepticus induced by thiocolchicoside in the rat. Seizure 2003; 12: 508-15.

[11] Pedro GB, Mara GB, Luciana KT, Luis FC, Antono AM, Jorge K. Epileptic seizure after treatment with thiocolchicoside. Therap Clin Risk Manag 2009; 5: 635-7.

[12] Siddiqui MR, Al Othman ZA, Rahman N. Analytical techniques in pharmaceutical analysis: a review. Arab J Chem 2013; Available online: http://dx.doi.org/10.1016/j.arabjc.2013.04.016

[13] Acharjya SK, Mallick P, Panda P, Annapurna MM. Spectrophotometric methods for the determination of thiocolchicoside in bulk and pharmaceutical dosage form. J Pharm Edu Res 2010; 1(1): 517.

[14] Joshi RR, Gupta KR. UV-spectrophotometric determination of thiocolchicoside in capsule. Der Pharm Chem 2010; 2(2): 384-91.

[15] Bhandari A, Nawal M, Jathalia R, Bhandari M, Solanki R, Nagori BP. UV spectrophotometric etermination of thiocolchicoside from capsule dosage form. J Pharm Res 2011; 4(12): 4685-7.
Suganthi A, Ravi TK. Development of validated spectrofluorimetric method for the estimation of thiocolchicoside. Int $\mathrm{J}$ ChemTech Res 2012; 4(4): 1674-80.

Umarkar AR, Bagad YM, Rewatkar NS, Thote LT. Simultaneous spectrophotometric estimation of thiocolchicoside and diclofenac potassium in combined capsule dosage form. Asian J Res Chem 2011; 4(3): 370-2.

Choudhari VP, Chabukswar AR, Savakhande SN, Tryambake MU, Suryawanshi V, Smsayal PK. Simultaneous spectrophotometric estimation of thiocolchicoside and diclofenac potassium in combined dosage form by ratio derivative and dual wavelength method. Int J Curr Res Rev 2010; 2 (12): 3-10.

[19] Choudhari VP, Chabukswar AR, Mangesh UT, Sachin NS. Spectrophotometric simultaneous determination of diclofenac potassium B.P. and thiocolchicoside in combined tablet dosage form by absorption corrected method and area under curve method. Int $\mathrm{J}$ Pharm Sci Rev Res 2011; 7(2): 182-5.

[20] Vilas D, Patil RY. Chaudhari spectrophotometric method for estimation of thiocolchicoside and diclofenac potassium in capsule dosage form by simultaneous equation method. Int J Drug Discov Herb Res (IJDDHR) 2012; 2(2): 410-2.

[21] Umarkar AR, Rewatkar NS, Charde MS, Charde RM. Simultaneous estimation of thiocolchicoside and diclofenac potassium by $u v$ spectrophotometer using multicomponent method. Int J Chem Tech Res 2011;3(2): 944-7.

[22] Sengar MR, Gandhi SV, Patil UP, Rajmane VS. Simultaneous determination of diclofenac sodium and thiocolchicoside in fixed dose combination by spectrophotometry. Asian J Pharm Clin Res 2010; 3(2): 89-91.

[23] Joshi RR, Gupta KR. Simultaneous UV-spectrophotometric determination of thiocolchicoside and diclofenac in pharmaceutical formulation. Der Pharm Sin 2010; 1(2): 44-51.

[24] Umarkar AR, Bagad YM, Bhurat MR, Kawatikwar PS. Absorption correction method for estimation of thiocolchicoside and diclofenac potassium in combined capsule dosage form. Int J Pharm Sci 2011; 3(1): 1046-9.

[25] Chitlange SS, Shinde PS, Pawbake GR, Wankhede SB. Simultaneous estimation of thiocolchicoside and aceclofenac in pharmaceutical dosage form by spectrophotometric and LC method. Der Pharmacia Lett 2010; 2(2): 86-93.

[26] Thankappan S, Parmar A, Sailor B, Vekariya K, Shah D. Simultaneous estimation of etodolac and thiocolchicoside by uv spectrophotometric method in tablet formulation. Int J Pharm Innov 2012; 2(2): 192-200.

[27] Harde MT, Dharam DL, Jadhav SB, Balap AR. Development and validation of rp-hplc method for simultaneous estimation of thiocolchicoside and dexketoprofen in bulk and tablet dosage form. Int J Pharm Tech Res 2012; 4(4): 1797-1802.

[28] Wankhede SB, Zambare SS, Chitlange SS. Estimation of thiocolchicoside and ketoprofen in pharmaceutical dosage form by spectrophotometric methods. J Pharm Res 2010; 3(4): 707-10.

[29] Hapse SA, Thorave RR, Kadaskar PT, Shirsath AS, Dokhe DM Novel spectrophotomeric method for simultaneous estimation \& validation of paracetamol, thiocolchicoside and aceclofenac in tablet dosage form by UV spectrophotometer. J Pharm Res 2011; 4(11): 3928-9.

[30] Nikhade RD, Thakur AD, Choudhari SB, Chandewar AV. Simultaneous estimation of paracetamol, thiocolchicoside and aceclofenac by $u v$ spectrophotometer using multicomponent mode method. J Pharm Res 2011; 4(7): 2297-9.

[31] Walash M, Belal F, Eid M, Abo ES. Simultaneous HPLC determination of thiocolchicoside and glafenine as well as thiocolchicoside and floctafenine in their combined dosage forms. J Chromatogr Sci 2011; 49: 159-64

[32] Chaudhari SB, Bais YG, Umarkar AR. Development of RP-HPLC method for simultaneous estimation of thiocolchicoside and aceclofenac in their pharmaceutical preparation. J Pharm Res 2011; 4(10): 3638-40.

[33] Chitlange SS, Shinde PS, Pawbake GR, Wankhede SB. Simultaneous estimation of thiocolchicoside and aceclofenac in pharmaceutical dosage form by spectrophotometric and LC method. Der Pharmacia Lett 2010, 2(2): 86-93.

[34] Reddy VS, Dutt KR. Development and validation of RP-HPLC method for simultaneous estimation of Aceclofenac and Thiocolchicoside in tablet dosage form. Int J Pharm Anal Res 2014; 3 (1): 30-7. 
[35] Rele RV, Sawant SA. Simultaneous determination of aceclofenac and thiocolchicoside in formulation by reversed phase high performance liquid chromatography. Am J Pharm Tech Res 2012; 2(4): 45-49.

[36] Umarkar AR, Rewatkar NS, Charde MS, Charde RM, Kasture AV. RP-HPLC method development and validation for estimation of thiocolchicoside and diclofenac potassium in bulk and capsule dosage forms. J Pharm Res 2011; 4(5): 1307-8.

[37] Sabitha M, Mahaboobsubhani M, Reddy CBS. Analytical method development and validation for the simultaneous estimation of diclofenac sodium and thiocolchicoside in tablet dosage form by using RP-HPLC. Int Res J Pharm Appl Sci 2014; 4(2): 7-13.

[38] Sahoo M, Syal P, Ingale S, et al. Development and validation of a RP-HPLC-PDA method for simultaneous determination of lornoxicam and thiocolchicoside in pharmaceutical dosage form and its application for dissolution study. Int J Res Pharm Sci 2011; 2(1): 17 .

[39] Modi MV, Patel MM, Patel CN. Development and validation of analytical method for the determination of lornoxicam and thiocholchicoside in pharmaceutical dosage form by reversed-phase HPLC. Int J Chem Tech Res 2011; 3(3): 1259-64.

[40] Bhavsar SM, Patel DM, Amit APK, Patel CN. Validated RP-HPLC method for simultaneous estimation of Lornoxicam and Thiocolchicoside in solid dosage form. J Chem Pharm Res 2010; 2(2): 56372.

[41] Harikiran OV, Rao MP, Rao DN, Gayathri DK, Sivasankar RB. Development and validation of a RP-HPLC method for simultaneous determination of lornoxicam and thiocolchicoside in Pharmaceutical dosage form. Int J Pharm Integr Life Sci 2013; 1(11): 1520.

[42] Wankhede SB, Zambare SS, Dixit NR, Chitlange SS. RP-HPLC method for simultaneous estimation of thiocolchicoside and ketoprofen in combined dosage form. Der Pharma Lett 2010; 2(3): 31520.

[43] Abirami G, Vetrichelvan T. A new RP-HPLC method for simultaneous estimation of thiocolchicoside and ketoprofen in tablet dosage form. World J Pharm Pharm Sci 2015; 3(2): 2564-75.

[44] Bhavnani VS, Gandhi SV, Deshpande PB, Dhiware AD, Potawale SE. A simple and sensitive RP-HPLC method for simultaneous estimation of dexketoprofen and thiocolchicoside in combined tablet dosage form. Der Pharm Sin 2012; 3(4): 433-6.

[45] Harde MT, Dharam DL, Jadhav SB, Balap AR. Development and validation of RP-HPLC method for simultaneous estimation of thiocolchicoside and dexketoprofen in bulk and tablet dosage form. Int J PharmTech Res 2012; 4(4): 1797-802.

[46] Kumar S, Joshi A, Thakur RS, Pathak AK, Shah K. Simultaneous estimation of etoricoxib and thiocolchicoside by RP-HPLC method in combined dosage forms. Acta Pol Pharm Drug Res 2011; 68(6): 839-45.

[47] Goyal N, Bhandari A, Jain S, Patel R. Method development and validation of etoricoxib and thiocolchicoside in combined pharmaceutical solid dosage form by RP-HPLC method. Int J Pharm Stud Res 2011; 2: 106-9.

[48] Suresh KS, Natraj D, Khan A, Kumar KB, Rao VJ. Development and validation of RP-PLC method for simultaneous estimation of etoricoxib and thiocolchicoside in pharmaceutical dosage forms. Int J Res Pharm Chem 2011; 1(3): 649-53.

[49] Rathod K, Patel J. Simultaneous estimation of etodolac and thiocolchicoside in their combined marketed formulation by RP-HPLC. Int PharmTech Res 2012; 4(4): 1513-9.

[50] Dhiware AD, Gandhi SV, Deshpande PB, Bhavnani VS. A Simple and sensitive rp-hplc method for simultaneous estimation of etodolac and thiocolchicoside in combined tablet dosage form. Int $\mathrm{J}$ Pharm Pharm Sci 2012; 4(4): 214-6.

[51] Alagar RM, Priyadarshini CH, David B, Rao KNV, Selvakumar D. Validated RP-HPLC method for simultaneous estimation of etodolac \& thiocolchicoside in pharmaceutical tablet dosage form. J Pharm Res 2012; 5(8): 4577-9.

[52] Chiragkumar M, Patel BM, Kunal DB, Ronak AP, Smit AS, Joshi PR. Development and validation of analytical method for simultaneous estimation of paracetamol and thiocolchicoside by RP-HPLC in bulk and pharmaceutical dosage form. Pharm Sci Monit 2013; 4(3): 296-306.

[53] Dhaneshwar SR, Raut KO, Bhusari VK. Validated HPLC method for simultaneous estimation of paracetamol, aceclofenac and thio- colchicoside in bulk drug and formulation. Res J Pharm Bio Chem Sci $2011 ; 2(2)$ : 435-45.

[54] Rele RV, Mali RN. Advance simultaneous determination of paracetamol, thiocolchicoside and aceclofenac in tablets by reverse phase high performance liquid chromatography. Der Pharm Sin 2014; 5(1): 34-9.

[55] Gandhi S, Deshpande P, Sengar M. High performance thin layer chromatographic determination of diclofenac sodium and thiococlhicoside in fixed dose combination. Int Res J Pharm 2010; 1(1): 220-4.

[56] Shrivastav J, Shah K, Mahadik M, Dhaneshwar SR. Application of HPTLC in the simultaneous estimation of thiocolchicoside and diclofenac in bulk drug and pharmaceutical dosage form. Bull Pharm Res 2011; 1(3): 34-7.

[57] Patil ST, Bhusari VK, Dhaneshwar SR. Validated HPTLC method for simultaneous estimation of thiocolchicoside and aceclofenac in bulk drug and formulation. Int J Pharm Bio Sci 2011; 2(2): 482-90.

[58] Syal P, Sahoo M, Raut RP, et al. Development and validation of an HPTLC method for simultaneous estimation of thiocolchicoside and aceclofenac in combined dosage form. J Planar Chromatogr 2012; 25(2): 133-7.

[59] Siyal P, Swarnkar G, Sahoo M. The development and validation of hptlc method for the simultaneous estimation of thiocolchicoside and aceclofenac in pharmaceutical dosage form. Int $\mathrm{J}$ Pharm Erud 2011; 1(3): 1-9.

[60] Bhavnani VS, Gandhi SV, Deshpande PB, Dhiware AD. High Performance Thin Layer Chromatographic determination of dexketoprofen and thiocolchicoside in combined tablet dosage form. $\mathrm{J}$ Chem Pharm Res 2012; 4(6): 3324-8.

[61] Harde M, Dharam D, Jadhav S, Chaudhari P, Balap A. Development and validation of hptlc method for the simultaneous estimation of thiocolchicoside and dexketoprofen in bulk and tablet dosage form. J Pharm Res 2012; 5(8): 4143-6.

[62] Sahoo M, Sayal P, Hable AA, Raut RP, Chaudhari VP, Kuchekar BS. Development and Validation of HPTLC Method for the Simultaneous Estimation of Lornoxicam and Thiocolchicoside in Bulk and Tablet Dosage Form. Pharm Methods 2011; 2(3): 178-83.

[63] Rajmane VS, Gandhi SV, Patil UP, Mahimar S. High-performance thin-layer chromatographic determination of etoricoxib and thiocolchicoside in combined tablet dosage form. J AOAC Int 2010; 93(3): 783-6.

[64] Erika DG, Silvio A, Giorgio G. Forced degradation study of thiocolchicoside: Characterization of its degradation products. J Pharm Biomed Anal 2012; 61: 215-23.

[65] Sutherland FC, Smit M, Herbst JL, et al. Highly specific and sensitive liquid chromatography-tandem mass spectrometry method for the determination of 3-desmethylthiocolchicine in human plasma as analyte for the assessment of bioequivalence after oral administration of thiocolchicoside. J Chromatogr A 2002; 949(1-2): 71-7.

[66] Sandouk P, Bouvier M, Chretien P, Tillement JP, Scherrmann JM. Single-dose bioavailability of oral and intramuscular thiocolchicoside in healthy volunteers. Biopharm Drug Dispos 1994; 15(1): 8792.

[67] Perucca E, Poitou P, Pifferi G. Comparative pharmacokinetics and bioavailability of two oral formulations of thiocolchicoside, a gabamimetic muscle relaxant drug, in normal volunteers. Eur J Drg Met Pharmacok 1995; 20(4): 301-5.

[68] Agarwal S, Das A, Chowhury HR, Sarkar AK, Chattaraj TK, Pal TK. Bioequivalence study of fixed dose combination tablet containing lornoxicam and thiocolchicoside in healthy subjects. Int $\mathrm{J}$ Pharm Sci Res 2011; 2(10): 2718-23.

[69] Kumar P, Shukla S, Subudhia BB, Ganure AL. Bioanalytical method development and validation for the simultaneous estimation of thiocolchicoside and lornoxicam in human plasma and in pharmaceutical dosage form by RP-HPLC. Int J Pharm Pharm Sci 2012; 4(3): 252-9.

[70] Tapan KP. Bioanalytical method development and validation for the simultaneous estimation of active metabolite thiocolchicoside and diclofenac in human plasma by LCMS/MS with a special emphasis to bioequivalence study. J Bioequiv Availab 2013; 5(3): 112.

[71] Pandey R, Patil PO, Bari SB, Dhumal DM. Simultaneous estimation of etodolac and thiocolchicoside in bulk and in tablet formulation by uv-spectrophotometry. Chem Ind Chem Eng Q 2014; 20(1): $9-17$. 
[72] Umarkar AR, Rewatkar NS, Chaple DR, Thote LT, Chaudhari SB, Bhurat MR. Stability Indicating RP-HPLC method for estimation of thiocolchicoside in capsule dosage forms. Res J Pharm Bio Chem Sci 2011; 2(10): 750-6.

[73] Joshi RR, Gupta KR, Jinnawar KS, Wadodkar SG. Development and validation of stability indicating RP-HPLC method for determination of thiocolchicoside in capsule. Am J Pharm Tech Res 2012; 2(1): 590-602.

[74] Rajput DK, Shirkhedkar AA, Rajput JK, Patel HM, Surana SJ. Stability studies of thiocolchicoside in bulk and capsules using RPHPTLC/densitometry. J Anal Method Chem 2013; Article ID $142628,1-7$.

[75] Darode GS, Ghodeswar BC, Thorat SD, Phawade PP, Chaudhari SR. Development and validation of stability indicating assay method for simultaneous estimation of etodolac and thiocolchicoside in bulk and tablet dosage form by rp-hplc method. Int J Pharm Res Develop 2013; 5(05): 8-14.

[76] Ganta S, Suryadevara V, Ganji R, Srilakshmi V. Method development and validation of stability indicating rp-hplc method for simultaneous estimation of thiocolchikoside and aceclofenac in bulk and its pharmaceutical formulations. Int J Bioassays 2014; 3(04): 2059-65.

[77] Jadhav SD, Butle SR, Patil SD, Jagtap PK. Validated stability indicating RP-HPLC method for simultaneous determination and in vitro dissolution studies of thiocolchicoside and diclofenac potassium from tablet dosage form. Arab J Chem 2011; (doi:10.1016/j.arabjc.2011.01.018)
[78] Satyanarayana MV, Satyadev TN, Ganji R, Anuradha V. Method development and validation of stability indicating RP-HPLC method for simultaneous estimation of thiocolchicoside and diclofenac in bulk and its pharmaceutical formulations. Indo Am J Pharm Res 2014; 4(3): 2014.

[79] Choudhari VP, Raut RP, Sahoo M, et al. Development and validation of Stability-indicating RP-HPLC-PDA method for simultaneous analysis of thiocolchicoside and aceclofenac in pharmaceutical dosage form. J Pharm Res 2011; 4(6): 1820-3.

[80] Samanthula G, Shrigod VV, Patel PN. Validated stabilityindicating assay method for simultaneous determination of aceclofenac and thiocolchicoside using RP-HPLC. Drug Res 2014; 64(8): 429-35.

[81] Balan P, Kannappan N. Development and validation of stabilityindicating RP-UPLC method for simultaneous estimation of thiocolchicoside and aceclofenac in combined dosage form. Int Curr Pharm J 2014; 3(7): 296-300.

[82] Wankhede SB, Chitlange SS, Bhole RP, Zambare SS. A simple and sensitive HPTLC method for simultaneous analysis of Thiocolchicoside and Ketoprofen in combined dose tablet formulation. Anal Chem Lett 2012; 2(5): 301-8.

[83] Deshpande S, Patel AR. Stability indicating simultaneous estimation of Thiocolchicoside, Paracetamol and diclofenac sodium in bulk drug and formulation by RP-HPLC. World J Pharm Sci 2014; 2(7): 671-8.

[84] Indian Pharmacopeia $6^{\text {th }}$ ed, Govt. of India, Ministry of Health and Family Welfare, Gaziabad, 2010: vol-III, pp. 2213-4.

(C) Rajput et al.; Licensee Bentham Open.

This is an open access article licensed under the terms of the (https://creativecommons.org/licenses/by/4.0/legalcode), which permits unrestricted, noncommercial use, distribution and reproduction in any medium, provided the work is properly cited. 